\title{
Using electrical resistivity tomography to detect wetwood and estimate moisture content in silver fir (Abies alba Mill.)
}

\author{
Ludovic Martin ${ }^{1}$ (D) $\cdot$ Hervé Cochard ${ }^{1}$ (D) $\cdot$ Stefan Mayr $^{2}$ (D) Eric Badel $^{1}$ (D)
}

Received: 25 March 2021 / Accepted: 16 June 2021

(C) INRAE and Springer-Verlag France SAS, part of Springer Nature 2021

\begin{abstract}
- Key message Using several experimental approaches, we have demonstrated that electrical resistivity tomography (ERT) is a reliable nondestructive tool for estimating the moisture content of heartwood in situ. ERT measurements show that water pockets in heartwood (wetwood) are present in a large majority (90\%) of silver fir (Abies alba Mill.) trunks.

- Context For wood professionals, the presence of wetwood in wood logs leads to an increase in costs, especially during the drying process. Assessing these internal properties in situ with a nondestructive method will provide reliable information for improved management of respective forests.

- Aims The objective of this study was to evaluate the efficiency of the electrical resistivity tomography (ERT) tool to detect wetwood in standing trees and to estimate the mean moisture content (MC) of silver fir trunks.

- Methods The study was carried out in 3 forests located in the region "Massif Central" in France. We selected 58 silver fir trees, visually healthy and without visible default. Each tree has been subject to regular ERT measurements for more than a year. At the same time, one to three cores were taken from each tree in order to measure the actual MC of the wood.

- Results $90 \%$ of the silver fir trees showed the presence of wetwood in their heartwood. Our results showed a significant correlation between the mean heartwood MC measured on cores and the mean electrical resistivity (ER) obtained with ERT.

- Conclusion (i) The presence of wetwood occurs in a high proportion of the silver fir trees studied, and (ii) ERT can be used to estimate the average MC of the heartwood of standing trees. However, the data provided by ERT vary seasonally and do not allow the precise location of wetwood.
\end{abstract}

Keywords Electrical resistivity tomography $\cdot$ Wetwood $\cdot$ Abies alba $\cdot$ Moisture content $\cdot$ Nondestructive testing

Handling Editor: Jean-Michel Leban

Ludovic Martin

ludovicmartin63@yahoo.fr

Hervé Cochard

herve.cochard@inrae.fr

Stefan Mayr

Stefan.Mayr@uibk.ac.at

Eric Badel

eric.badel@inrae.fr

1 Université Clermont Auvergne, INRAE, PIAF, 63000 Clermont-Ferrand, France

2 Department of Botany, University of Innsbruck, Innsbruck, Austria

\section{Introduction}

Wetwood or water pockets are localized areas where the moisture content (MC) of the heartwood is abnormally high and can reach or exceed the level of the sapwood MC (Jeremic et al. 2004; Schneider and Zhou 1989). Wetwood is common in Abies species and has been studied during the end of the twentieth century in North American Abies baslsamea Mill. (Jeremic et al. 2004; Lihra et al. 2000; Schneider and Zhou 1989), Abies grandis Lindl. (Coutts and Rishbeth 1977), and Abies Concolor Lindl. (Worrall and Parmeter 1982). The precise causes and processes of wetwood formation are still not clearly identified (Shaw et al. 1995). It has been hypothesized that wetwood is the result of bacterial contamination (Schink and Ward 1984). Other studies have postulated that dead branches, branch breakage, and mechanical injury may lead to wetwood formation (Bonsen and Walter 1993; Etheridge 
and Morin 1962; Shaw et al. 1995). Finally, others have suggested that wetwood in heartwood could result from water transfer from the sapwood (Coutts and Rishbeth 1977; Nakada et al. 2019). The main technological issues of wetwood are increasing in drying times, generally accompanied by a high shrinkage of the pieces, final heterogeneous MC distributions, and higher manufacturing costs (Chafe 1996; Kozlik and Ward 1981; Shaw et al. 1995; Ward and Pong 1980). In Europe, the wood processing industry encounters the same problem with the native species Abies alba (silver fir). Silver fir is a main resinous species in the humid mountainous regions of central and southern Europe. However, due to the presence of irregular and frequent areas of wetwood in the trunks, it is frequently less exploited than other species located in the same areas and presenting wood with identical properties such as Picea abies (L.) Karst. Detecting the water pockets and estimating the local MC distribution in trunks in a nondestructive way directly in the forest would be useful for better optimization of the resource of silver fir trees.

The moisture content of trees has been studied using different methods on samples taken from trees and analyzed in the laboratory. The most common method is the kiln drying method giving precise values of the total water content of wood samples (Krause and Gagnon 2005; Krause and Gagnon 2006; Worrall and Parmeter 1982). Other methods, such as near-infrared spectroscopy (Watanabe et al. 2012) or X-ray scanning (Alkan et al. 2007), have been proposed to detect the presence of wetwood on lumber during processing in sawmills. At the cellular level, X-ray microtomography allows the visualization of water-filled versus the gas-filled status of individual xylem conduits and can give a precise description of embolized tissues (Cochard et al. 2015; Suuronen et al. 2013).

Electrical resistivity tomography (ERT) is a nondestructive promising technique that was first developed for geophysical sciences (Al Hagrey 2007; Revil et al. 2012). Since the first adaptation for studying living trees by Just and Jacobs in 1998, ERT was increasingly used for several applications, such as detection of fungal infections and internal wood decay (Bieker et al. 2010; Humplik et al. 2016), or estimation of sapwood areas in coniferous species (Bieker and Rust 2010b; Guyot et al. 2013). More recently, it was also used to detect red heartwood in beech (Goncz et al. 2018) and false heartwood in poplar (Baettig et al. 2017). The measuring principle is based on a circular network of electrodes around the trunk, connected to the sapwood by small nails inserted through the bark. Step by step, an electric field is induced by two electrodes and recorded pairwise by the other inserted electrodes. The cross-sectional distribution of electrical resistivity (ER) is then obtained by processing the measured data on the basis of an inversion algorithm, which uses triangular meshes between the measurement points (Gunther et al. 2006;
Martin and Gunther 2013). 2D mapping using a color scale then allows visualizing ER distribution patterns for each tree. ERT technique is based on the local variability of ER in wood, which is highly influenced by MC, but also by electrolyte concentration and wood density (Al Hagrey 2006; Al Hagrey 2007; Bär et al. 2019; Bieker and Rust 2010a; Bieker et al. 2010; Guyot et al. 2013; Skaar 1988). There is a high specificity of ER tomograms for each species: For instance, ER patterns of English oak seem to be highly influenced by electrolyte concentrations, while wood density is a major source of variability in beech (Bär et al. 2019; Bieker and Rust 2010a). On the contrary, ER patterns of conifers, in particular spruce, which presents a wood similar to that of silver fir, seem to be mainly influenced by MC (Bär et al. 2019).

The main objectives of this study were to determine the effectiveness of ERT (i) in detecting wetwood and (ii) in estimating heartwood $\mathrm{MC}$ in standing silver fir trees. The 2D ERT measurements were compared to several other (destructive) methods including the measurement of $\mathrm{MC}$ with the drying kiln method, direct observation of embolism at the cellular level with X-ray microtomography scanning of wood cores, and water pockets observation with a medical CT scanner at the trunk level. After validation, the ERT method was used for two additional experiments: (i) the nondestructive monitoring of seasonal fluctuations in wood ER and (ii) the monitoring of the drying dynamics of a standing tree trunk after girdling. We hypothesized that the treatment of sapwood by girdling would break the uptake of water, resulting in the drying of the standing tree by evapotranspiration and the removal of all water reservoirs from the trunk.

\section{Materials and methods}

\subsection{Study sites description and sampling of trees}

Silver fir trees (Abies alba) were sampled in three different forest plots at Puy-de-Dôme, France. The first two plots, Guery 1 and Guery 2, were located in the domanial forest of Guery in the Sancy (southwest part of the Puy-de-Dôme). Guery 1 is a monospecific forest of silver fir trees located $45^{\circ} 37^{\prime} 43^{\prime \prime} \mathrm{N}, 2^{\circ} 48^{\prime} 11^{\prime \prime} \mathrm{E}$, between 1110 and $1130 \mathrm{~m}$ above sea level, with a slope gradient of $15 \%$ in a northeast exposition. Guery 2 is a mixed forest of silver fir and beech trees located $45^{\circ} 38^{\prime} 18^{\prime \prime} \mathrm{N}, 2^{\circ} 19^{\prime} 4^{\prime \prime} \mathrm{E}$, between 1030 and $1080 \mathrm{~m}$ above sea level, with a slope gradient of 55\% in a west exposition. Trees from these two plots are subject to a mean annual temperature of $7.6^{\circ} \mathrm{C}$ and a mean annual precipitation of 1148 $\mathrm{mm}$. The third plot, Saint-Germain, was located in the Livradois (southeast part of the Puy-de-Dôme). SaintGermain is a monospecific forest of old silver fir trees located $45^{\circ} 29^{\prime} 6^{\prime \prime} \mathrm{N}, 3^{\circ} 31^{\prime} 32^{\prime \prime} \mathrm{E}$, on a plateau at $1040 \mathrm{~m}$ for one part and 
at $940 \mathrm{~m}$ above sea level, with a slope gradient of $30 \%$ in a northwest exposition for a second part. Trees from this plot are subject to a mean annual temperature of $8.9^{\circ} \mathrm{C}$ and a mean annual precipitation of $933 \mathrm{~mm}$.

A total of 58 healthy and straight-grown Abies alba (23 in Guery 1, 20 in Guery 2, and 15 in Saint-Germain) were selected including exclusively dominant or codominant trees without visible defects. The sampled silver fir trees had a diameter at breast height (DBH) between 28 and $70 \mathrm{~cm}$ (average $50 \mathrm{~cm}$ ), a height of 22 to $28 \mathrm{~m}$, an average age of 65 and 62 years for the plots in Guery 1 and Guery 2, respectively, and 124 years for the plot of SaintGermain (see Appendix Tables 1 and 2 for detailed information on the trees). To address the two main objectives, ERT and MC measurements were conducted during summer and early autumn 2018. Among the 58 sampled trees, 44 (15 in Guery 1, 20 in Guery 2, and 9 in SaintGermain) were used for the study of the seasonal fluctuations. Measurements were done between May 2018 and August 2019. One tree (number 14) in the Guery 1 forest was used for the girdling experiment. Three additional trees from Guery 2 forest were felled in early July 2109 for X-ray scanning measurements. The diameter of these 3 trees was around $38 \mathrm{~cm}$ in order to adjust their dimensions to the X-ray scanner requirements.

For comparison purposes, 7 spruce (Picea abies) (6 in Guery 1, 1 in Saint-Germain) and 5 Douglas (Pseudotsuga menziesii) (all in Saint-Germain) were selected in the same areas.

\subsection{Electrical resistivity tomography}

ERT measurements were performed using a commercial multichannel, multielectrode resistivity system (PICUS TreeTronic 3, Argus Electronic Gmbh, Rostock, Germany). For each tree, depending on their circumference, between 16 and 24 nail probes were hammered at breast height $(130 \mathrm{~cm})$ equally distributed around the trunk (see Appendix Tables 1 and 2 for detailed information on the trees). The depth was adjusted in order to ensure that the bark was totally penetrated and that the nail reached the sapwood of the xylem. Nails were inserted counter-clockwise and starting with a northward orientation (measuring point MP1). For long-term measurements, nails were lightly hammered again before each measurement to avoid problems of contact with the wood and replaced once after the first 6 months. The exact positions of nail probes and trees geometry were measured using an electronic caliper (PICUS Calliper Version 3, Argus Electronic Gmbh) connected via Bluetooth to the PICUS Treetronic 3 tomograph. For each ERT measurement, nail probes were connected via electrodes to the resistivity system. The system automatically determines the appropriate electric voltages it applies between all MPs, measures the intensity, and deduces the mean resistivity between the nails. Then, all data (geometry and ERT) are sent to the TreeTronic expert software Q74 (Argus Electronic Gmbh) on a laptop for a 2D reconstruction step. This reconstruction is based on an inversion scheme (Gunther et al. 2006) and allows the spatial distribution of resistivities to be computed in an irregular triangular mesh that covers the whole cross-section of the trunk. For easier visualization of the patterns, each triangle is colored according to its resistivity value. Information on triangle size, position, and ER value was calculated from overlapping resistivity values at each point by the software, and corresponding data were exported in an Excel file. As triangle areas varied depending on their radial position, the weighted electrical resistivity (ERw; $\Omega \mathrm{m}$ ) was calculated for each triangle as

$E R_{w}=\frac{E R^{*} A}{A_{\text {mean }}}$

where $\mathrm{A}\left(\mathrm{cm}^{2}\right)$ is the individual triangle area and $\mathrm{A}_{\text {mean }}$ $\left(\mathrm{cm}^{2}\right)$ is the mean area of all triangles. The average ER $\left(E R_{\text {mean }}\right)$ of each entire cross-section was then calculated as the mean of $\mathrm{ER}_{\mathrm{w}}$ of all triangles (Bär et al. 2019).

ER profiles were obtained by extracting ER values along a selected line of 2-cm width corresponding to a west/east orientation (see Fig. 1) or to the position of the wood cores (see Fig. 2).

\subsection{Local wood moisture content measurements on cores}

Between one and three wood cores were collected (96 in total) from each tree with a 5-mm width increment borer (Haglöf Sweden AB, Lansele, Sweden). In order to obtain the most homogeneous samples in terms of wood density and to limit the presence of reaction wood, the samples were taken from vertical and straight trunks. To prevent a possible interaction with ERT measurements, the cores were taken between 5 and $10 \mathrm{~cm}$ below the level of ERT measurements. After sampling, the cores were cut into 10 -cm long pieces, placed immediately in plastic tubes, and brought to the laboratory in a cooler. Each piece was then cut into $10-\mathrm{mm}$ long samples, and its fresh mass (FW) was immediately weighted. Samples were then dried for at least $24 \mathrm{~h}$ at $104^{\circ} \mathrm{C}$, and their dried mass (DW) was weighted. Wood moisture content (MC \%) was then computed using the formula

$M C \%=\frac{\mathrm{FW}-\mathrm{DW}}{\mathrm{DW}} * 100$ 
Type 1
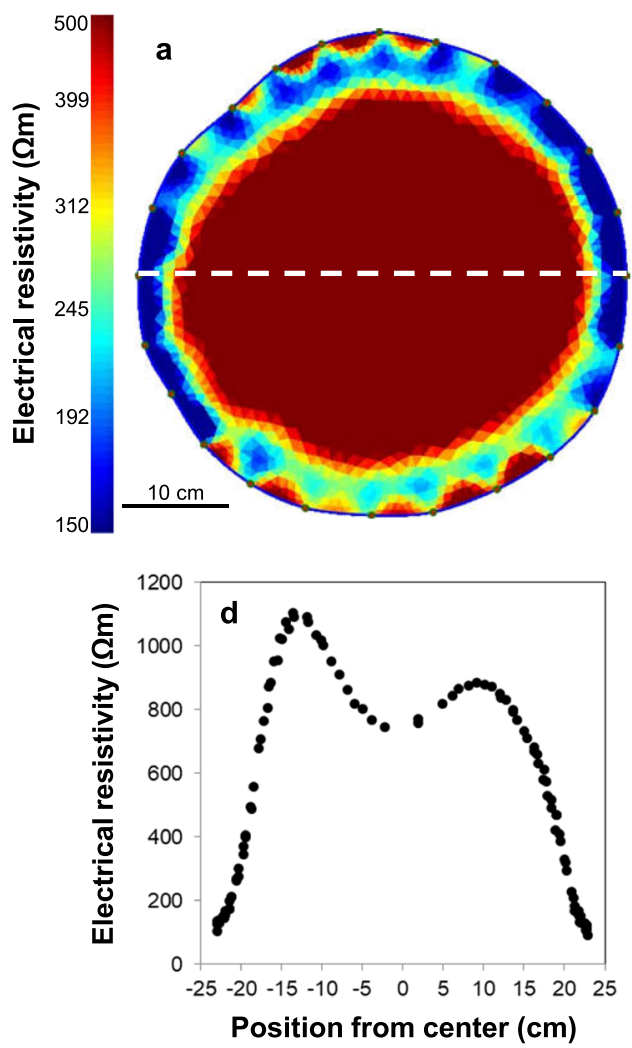

Type 2
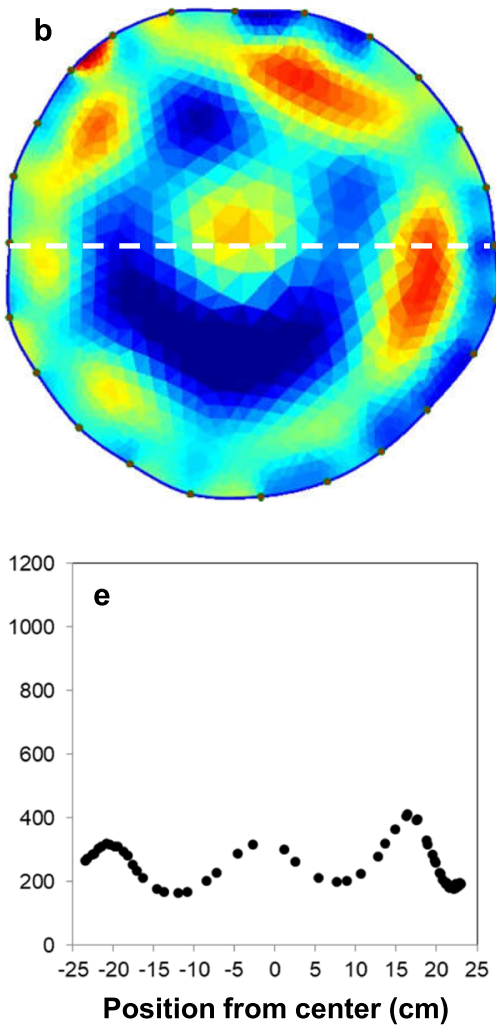

Type 3
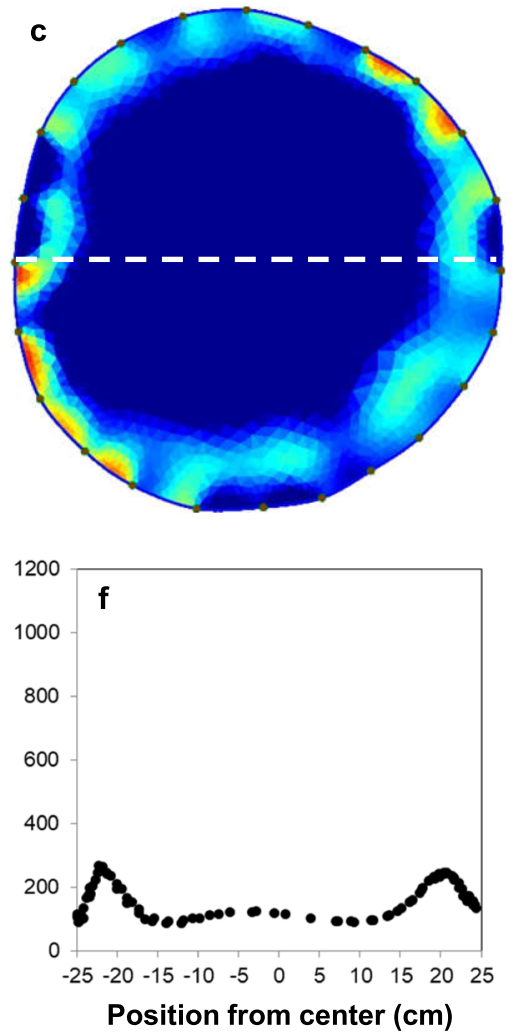

Fig. 1 Representative electrical resistivity (ER) tomograms (a, b, c) and corresponding radial distribution profiles $(\mathbf{d}, \mathbf{e}, \mathbf{f})$ obtained for the 58 studied trees. For easier comparison, the 3 examples come from the same plot and have a very similar diameter. The zones of high electric resistivity (ER) values $(\geq 400 \Omega \mathrm{m})$ in $2 \mathrm{D}$ tomograms are indicated by red colors, while the zones of low ER values $(\leq 200 \Omega \mathrm{m})$ are indicated by blue colors. To optimize the visualization of the tomograms, the limits of the displayed ER ranges have been manually set between 150 and $500 \Omega \mathrm{m}$; minimum/maximum ER values may exceed these limits. For each tomogram, ER values were extracted along a selected diameter of $2-\mathrm{cm}$ wide (white dotted line) corresponding to a west/east orientation of the trunk. Values of the ER profiles are displayed according to their position $(0 \mathrm{~cm}$ corresponds to the trunk center $)$

\subsection{Direct X-ray microtomography visualization of embolism at cell level in cores}

$\mathrm{X}$-ray microtomography (micro-CT) scans were performed on cores collected with a 10-mm width increment borer (Haglöf Sweden AB, Lansele, Sweden). The core was immediately wrapped in parafilm and brought to the laboratory in a cooler. At the laboratory, the cores were immediately coated with liquid paraffin wax in order to prevent drying. Then, they were placed in the X-ray microtomograph (Nanotom $180 \mathrm{XS}$; GE, Wunstorf, Germany), as described in Cochard et al. (2015). The field of view of the micro-CT scan was adjusted to $10 \mathrm{~mm}$ $\times 10 \mathrm{~mm} \times 10 \mathrm{~mm}$, and the X-ray source was set to $60 \mathrm{kV}$ and $240 \mu \mathrm{A}$. For each 21-min scan, 1000 images were recorded during the $360^{\circ}$ rotation of the sample. After a specific $3 \mathrm{D}$ reconstruction process, the spatial resolution of the final volumic image was $5.3 \mu \mathrm{m} \times 5.3 \mu \mathrm{m} \times 5.3 \mu \mathrm{m}$ per voxel. A virtual plane that depicts the radial-tangential plane was virtually extracted from the middle of the 3D volumes using VGStudio Max@ software (Volume Graphics, Heidelberg,
Germany) in order to visualize the local embolism at the cell level.

\subsection{CT scanning of logs}

CT scans were recorded on $12 \operatorname{logs}$ from 3 fir trees coming from Guery 2 plot with different ERT profiles. Trees were felled in early July 2019, and four 1-m long logs were cut at different heights on each tree. The logs were wrapped in plastic bags and brought in the "Xyloscience" plateform (Nancy, France). Each $\log$ was scanned by a medical CT scanner (GE BrightSpeed Excel). The spatial resolution in the transverse section $0.88 \mathrm{~mm} /$ pixel and the slice thickness was set to 0.625 $\mathrm{mm}$. Settings for the acquisition parameters were $80 \mathrm{kV}$ and $50 \mathrm{~mA}$ with a helical mode.

\subsection{Tree girdling experiment}

The girdling of tree number 23 from the Guery 1 plot was realized in early September 2018 using a chainsaw. 


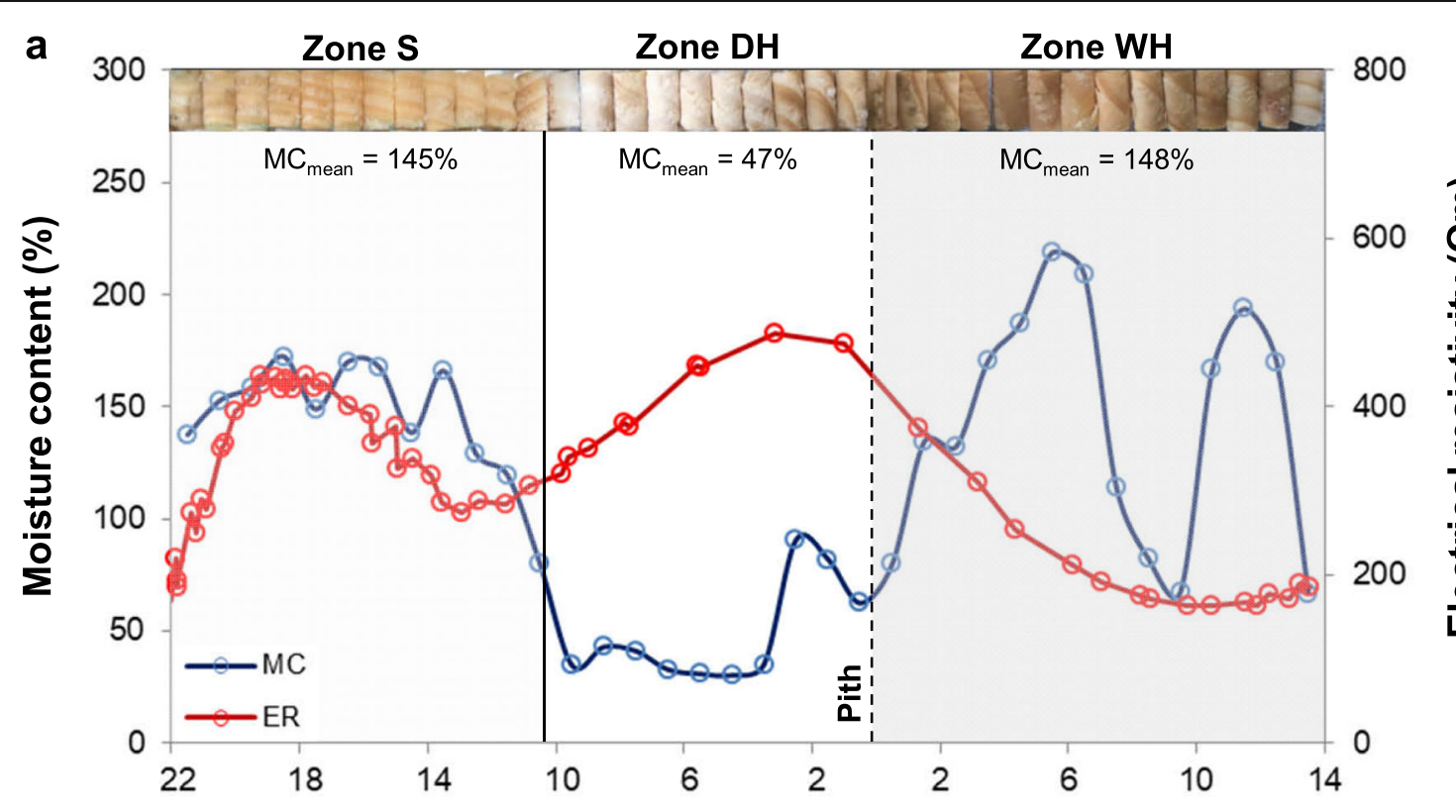

b

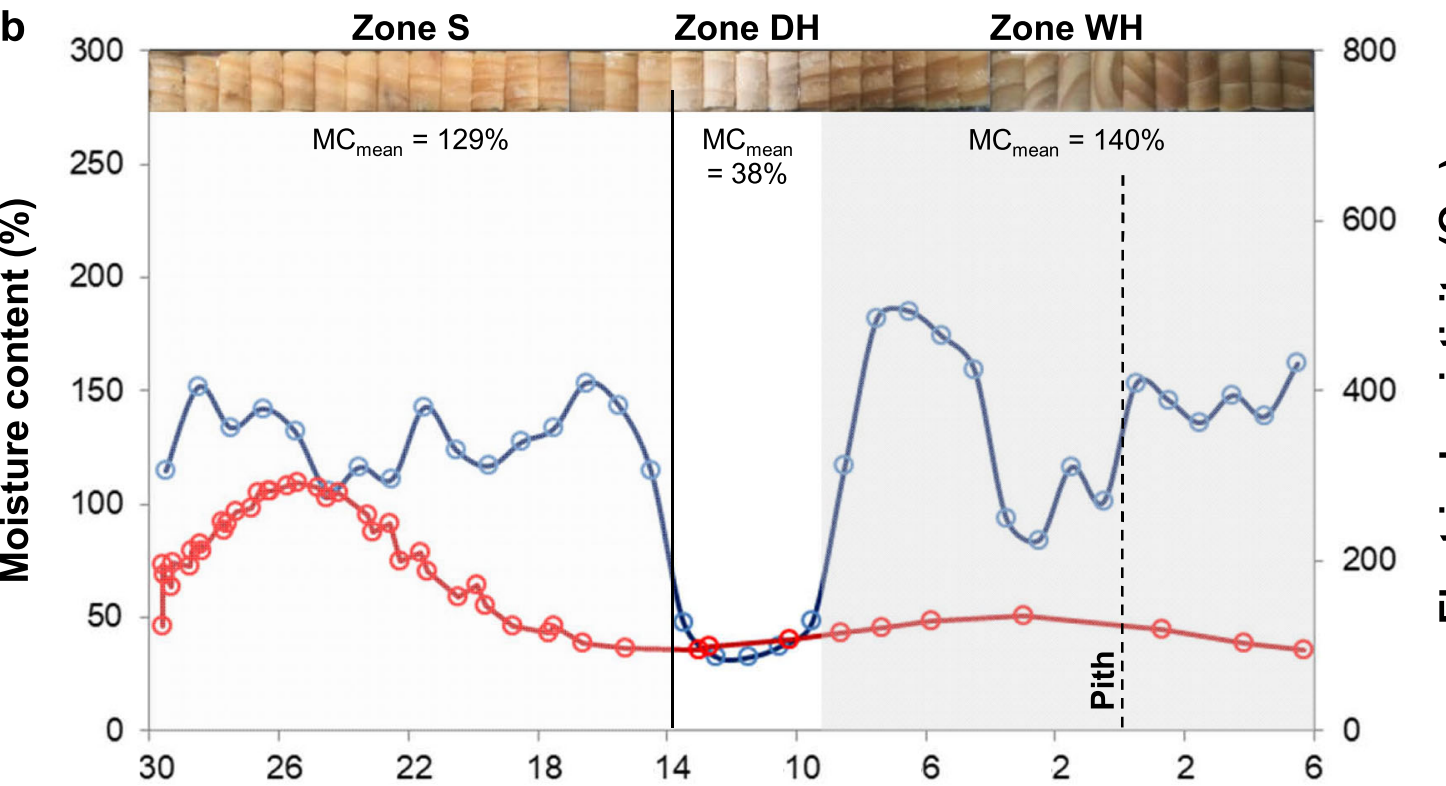

Fig. 2 Moisture content (MC) profiles of wood cores (blue) measured by fresh/dry wood weighing and corresponding electrical resistivity (ER) profiles (red) of two different trees $(\mathbf{a}, \mathbf{b})$. Each point of the MC profiles corresponds to the $1-\mathrm{cm}$ long core sample shown above. ER values were extracted along with a $2-\mathrm{cm}$ width corresponding to the position of the core. On each profile, the transition from sapwood to heartwood is

According to previous ERT and MC measurements, the trunk was notched at $50-\mathrm{cm}$ height to a depth of $10 \mathrm{~cm}$ to ensure that the flow of sap was completely stopped. ERT measurements and cores sampling were realized 1 $\mathrm{m}$ above the girdling zone on the day of girdling, and again 10 and 90 days later. represented by a solid black line and the stem center by a dotted black line. Three zones (zone S, zone DH, and zone WH) can be differentiated with the naked eye on the cores and are highlighted with different shades of gray on each profile. MC values and their corresponding ER values are displayed according to their position $(0 \mathrm{~cm}$ corresponds to the trunk center)

\subsection{Statistics}

Statistical analyses were performed using the RStudio software (under $\mathrm{R}$ core version 3.6.2, R Development Core Team, 2019). Data were tested for Gaussian distribution with a Shapiro-Wilk test. Kruskal-Wallis tests were combined 
Fig. $3 \mathrm{X}$-ray microtomographic observation of tracheids embolism on cores. Images $\mathbf{a}, \mathbf{b}$, and $\mathbf{c}$ correspond to the 3 different characteristic zones (zone $\mathrm{S}$, zone $\mathrm{DH}$, and zone $\mathrm{WH}$ ), respectively, observed in the fir trunks. Black areas indicate air-filled tracheids, and light-gray areas indicate water-filled tracheids. The boundaries between the 2 growth rings are indicated by red arrows. $E W$, earlywood; $L W$, latewood. Scale bar: $1 \mathrm{~mm}$

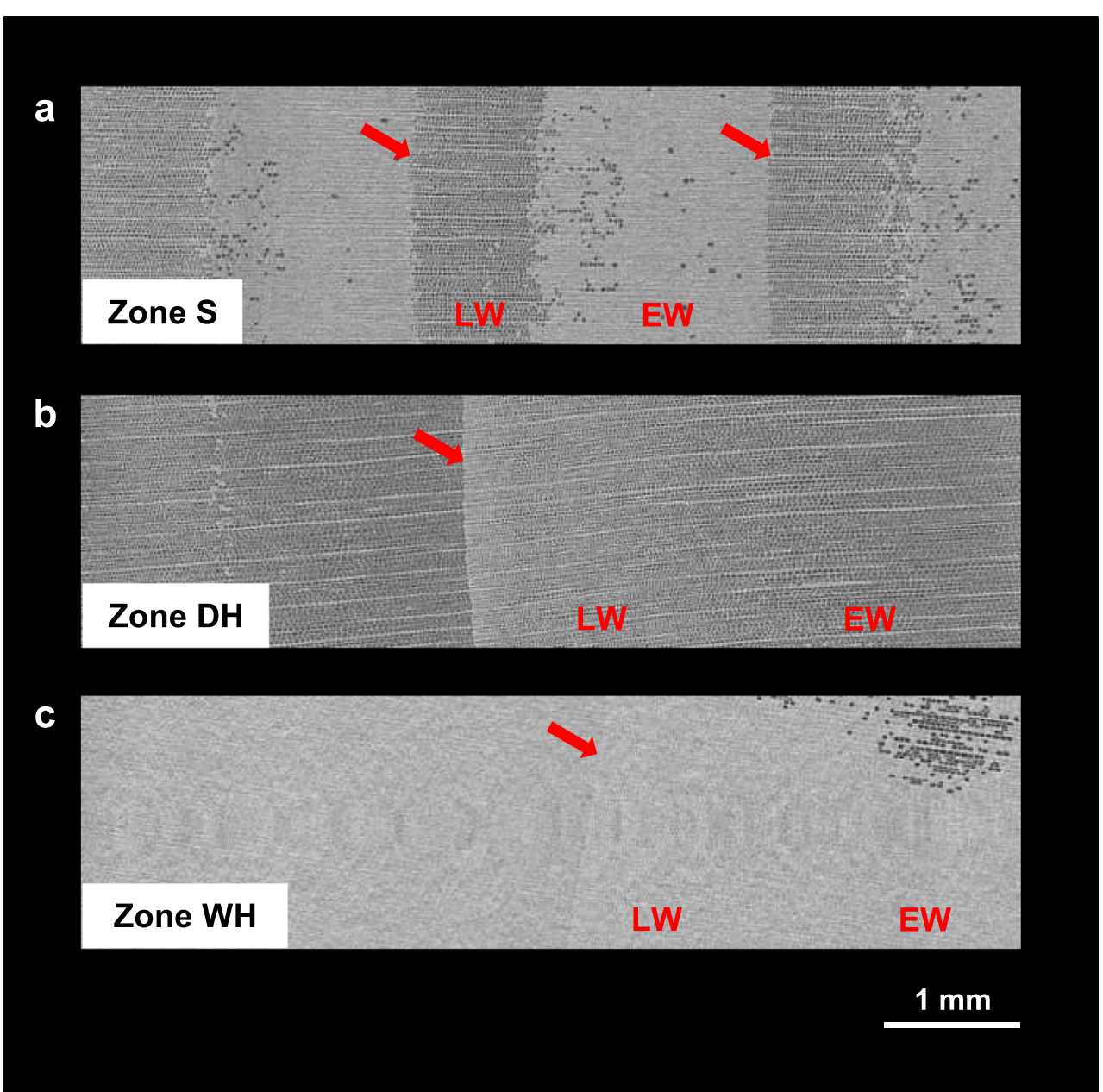

with Dunn's post-hoc tests to highlight statistically different groups. Correlations were tested at 0.01 probability level using Spearman's rank correlation coefficient to account for the non-normality of the data.

\section{Results}

During this study, nearly 500 ER measurements were made and 110 radial wood cores were collected (Badel et al. 2021). On all these wood cores, the distinction between sapwood and heartwood was made by direct visual observation.

\subsection{Electrical resistivity tomography}

The ER tomography was performed on 58 silver fir trees from 3 different forests. From these data, we extracted diametrical ER profiles. The results enlightened that the ER profiles could be separated into 3 types (Fig. 1). For type 1, the ER highly increased from the sapwood toward the center of the trunk (Fig. 1a, d). This type of ER tomograms was recorded for $10 \%$ of the trees (i.e., 6 trees out of the 58). The second type of ER profiles (type 2) showed significant overall variability with several areas of high (red), low (blue), and medium (yellow and green) ER parts in the heartwood (Fig. 1b, e). For this type of ER tomograms, recorded for $45 \%$ of the trees, the proportion and location of each zone were found to vary greatly between the 26 individuals. For the remaining $45 \%$ of trees (type 3 ), the measurements showed a low and quite homogenous ER in the entire cross-section (Fig. 1c, f). Contrary to type 1, the heartwood showed lower ER than the sapwood.

\subsection{Moisture content in annual rings and at the cellular level}

Local moisture content was measured at different radial positions on radial cores using the drying kiln method. The level of local embolism was observed at a cellular level by X-ray microtomography on similar radial cores. Depending on the cores, 2 or 3 different zones of wood could be seen to the naked eye. Two representative profiles are shown in Fig. 2.

The first zone (zone $\mathrm{S}$ ) corresponding to the sapwood appeared light brown to the naked eye (Fig. 2 upper parts). At the inter-ring level, this zone had a high $\mathrm{MC}$, generally above 


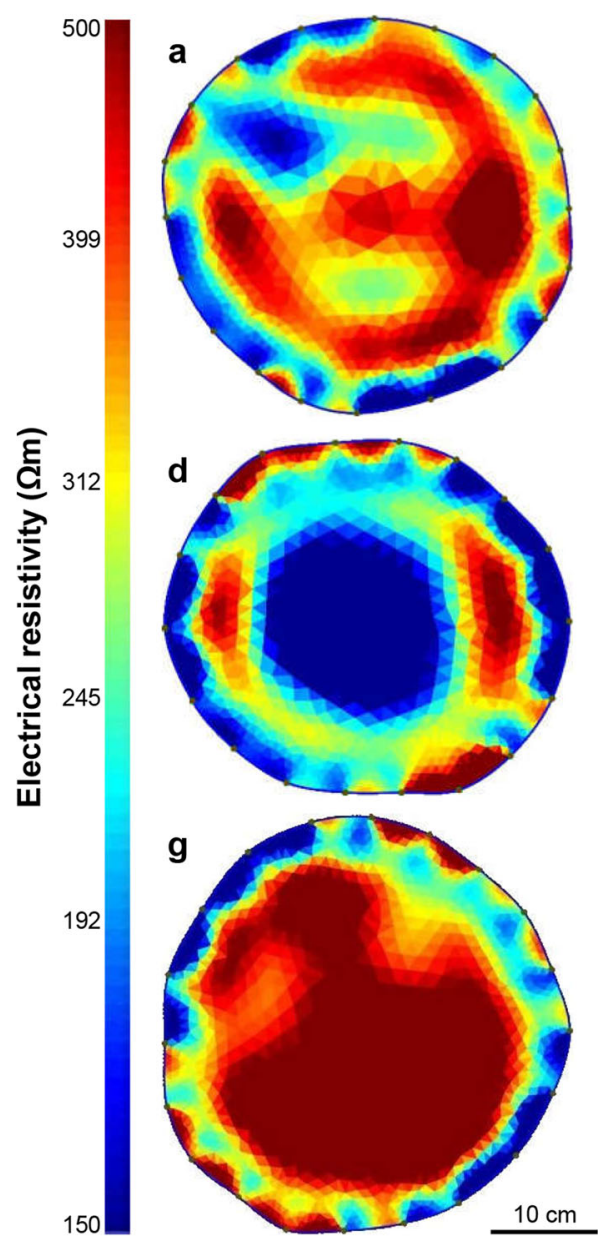

Fig. 4 ER tomograms $(\mathbf{a}, \mathbf{d}, \mathbf{g})$, corresponding cross-section $(\mathbf{b}, \mathbf{e}, \mathbf{h})$, and X-ray scanning images $(\mathbf{c}, \mathbf{f}, \mathbf{i})$ obtained for 3 logs. Areas of high resistivity in tomograms are indicated by red colors $(\geq 400 \Omega \mathrm{m})$, while

100\% (Appendix Table 1) and was relatively homogeneous (Fig. 2a, b). At the intra-ring level, X-ray microtomography showed an alternation of black areas, corresponding to embolized tracheids in the latewood and light-gray areas in the earlywood, where the lumens of the tracheids were mostly saturated with water. This pattern was identical in every tree ring constituting the sapwood (Fig. 3a).

In the heartwood, we could observe two very different areas (zone $\mathrm{DH}$ and zone $\mathrm{WH}$ ). The zone $\mathrm{DH}$, present in each core, appeared white to the naked eye. Drying kiln measurements showed that the wood in this zone was very dry, with a homogenous MC generally below $40 \%$ (Fig. 2a, b). Micro-CT images revealed a completely black area, highlighting that all the tracheids were fully embolized (Fig. 3b).

The third zone (zone WH), which was present in $83 \%$ of the cores (i.e., 48 of the 58 fir trees), appeared dark brown to the naked eye. In this zone, the wood was characterized by a very heterogeneous $\mathrm{MC}$, ranging from 40 to $270 \%$ in some extreme cases (Fig. 2a, b). Micro-CT images revealed entirely light-gray areas, showing fully water-saturated xylem, which spread over a few growth
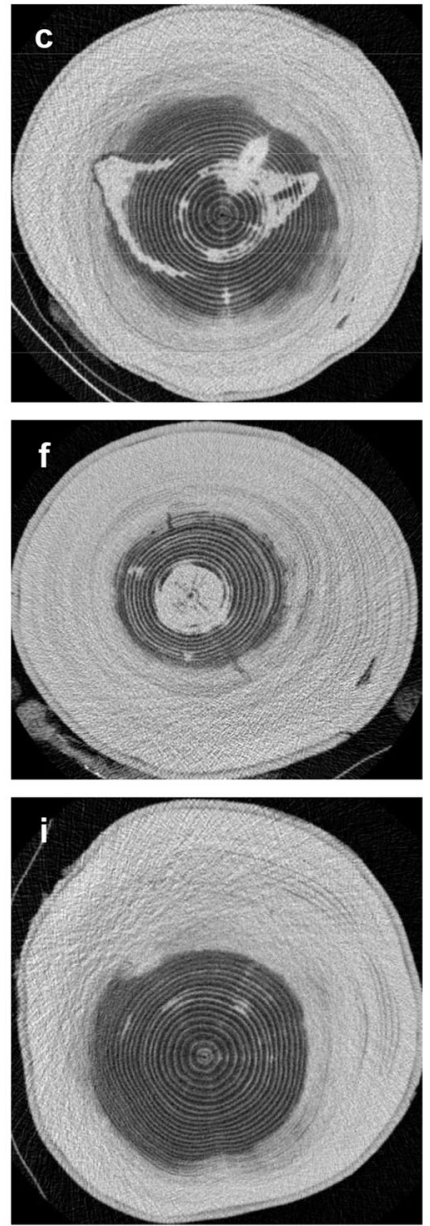

areas of low resistivity are indicated by blue colors $(\leq 200 \Omega \mathrm{m})$.On X-ray scanning images, black areas indicate partially air-filled tracheids and light-gray areas indicate the water-filled tracheids

rings in some trees and up to the entire heartwood in others. Generally, these light-gray areas were punctuated by black spots of varying sizes ranging from a few single water-filled tracheids to water-filled areas of several millimeters (Fig. 3c). The wood MC was negatively correlated to the level of tracheid embolism (data not shown).

\subsection{Mean electrical resistivity vs moisture content within trunk cross-sections}

A comparison of the MC profiles measured on the wood cores with the corresponding ER profiles was performed on 96 samples. Two representative examples are shown in Fig. 2. At the sapwood level (zone S), the profiles showed a short increase in ER followed by a decrease despite a relatively stable MC (Fig. 2a, b). This was observed for $90 \%$ of the ER profiles. At the heartwood level, as shown in Fig. 2a, the presence of large dry areas $(>8 \mathrm{~cm})$ led to an increase in ER. On the other hand, wetwood areas led to a strong decrease in ER values. In contrast, small dry areas $(<6 \mathrm{~cm})$ in large wet areas (like zone 2 in Fig. $2 \mathrm{~b}$ ) 

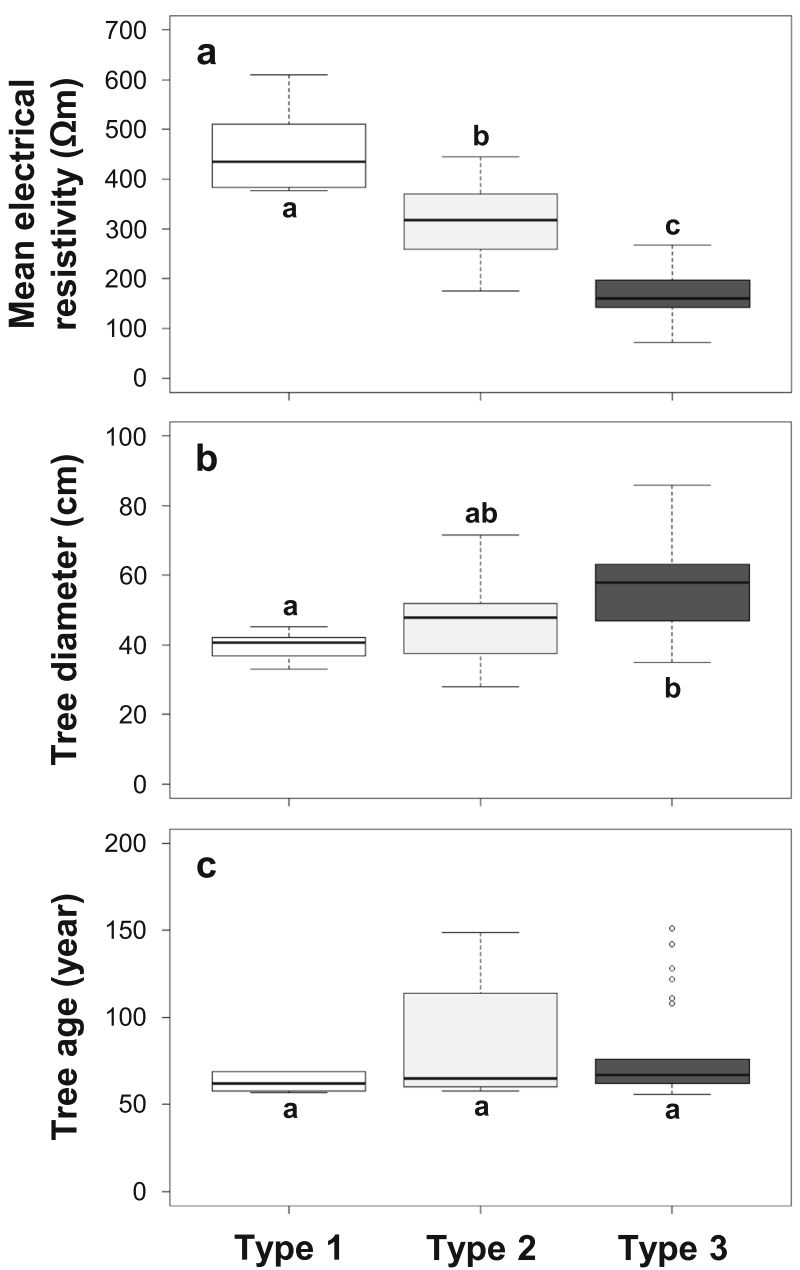

Fig. 5 Boxplots of average ER (a), tree diameter (b), tree age (c), and wood MC (d, e, f) for the 3 types of tomographic profiles observed (type $1: \mathrm{n}=6$; type $2: \mathrm{n}=26$; type $3: \mathrm{n}=26$ ). Mean electrical resistivity $\left(\mathrm{ER}_{\text {mean }} ; \Omega \mathrm{m}\right)$ was calculated from averaged values of each of the entire cross-section (a). Tree diameter was measured at breast height (b). Tree

and small wet areas in large dry areas were not visible on ER profiles. In addition, for 17 of the 96 samples, the radial ER profiles were strongly not related (more than $50 \%$ of the core length) to the MC values; $88 \%$ of these samples corresponded to trees displaying a type 2 ER profile, and 59\% came from the Guery 2 plot (data not shown). Finally, the comparison of ER tomograms with real radial cuts and 3D X-ray CT scanning images showed completely dry heartwood (Fig. 4g-i) and the presence of large homogenous wetwood areas (Fig. $4 \mathrm{~d}-\mathrm{f}$ ) but not heterogenous wetwood zones (Fig. $4 \mathrm{a}-\mathrm{c}$ ) were detected by ERT.

\subsection{Mean electrical resistivity vs moisture content at the trunk level}

The comparison of $\mathrm{ER}_{\text {mean }}$ obtained for the 58 trees studied revealed significant differences between the 3 types of
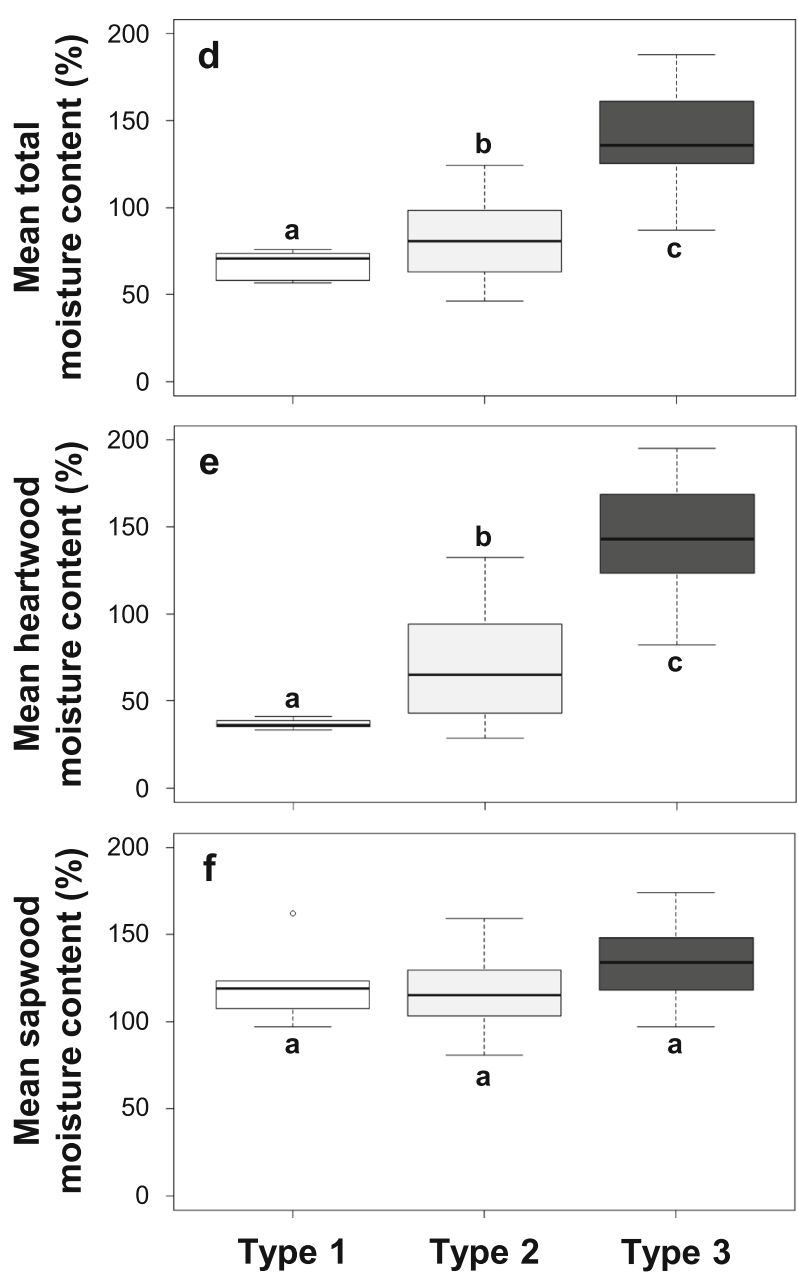

age (c), mean (d), heartwood (e), and sapwood (f) moisture content were measured using the wood core. Boxplots indicate the median (thick central line), interquartile range (box), minimum and maximum (whiskers), and outliers (circles). Different letters indicate significant differences

profiles presented in Fig. 1: Trees corresponding to type 3 showed an $\mathrm{ER}_{\text {mean }} 2$ to 3 times lower than those in type 2 and type 1 ER profiles, respectively (Fig. 5a). The decrease in $\mathrm{ER}_{\text {mean }}$ observed from type 1 to type 3 was partly associated with an increase in diameter (Fig. 5b), but not with the age of the trees studied (Fig. 5c). Decreasing $\mathrm{ER}_{\text {mean }}$ also corresponded to increasing mean wood MC, and more particularly to increasing heartwood MC (Fig. 5d, e). Indeed, heartwood MC was 2 and 4 times lower for trees showing type 1 compared to trees showing type 2 and type 3 ER profiles, respectively. Regarding sapwood MC, there were no statistical differences between the 3 types (Fig. 5f).

Correlation analysis revealed a strong influence of heartwood MC on mean MC, whatever the proportion of sapwood and heartwood (Fig. 6a). Finally, we observed a pronounced negative correlation between heartwood $\mathrm{MC}$ and $\mathrm{ER}_{\text {mean }}$ for the 58 studied trees (Fig. 6b). 
Fig. 6 Relationship between mean MC of the cross-section and mean heartwood MC (a), and between $\mathrm{ER}_{\text {mean }}$ and mean heartwood MC (b) for the 58 studied trees. Slope equations and correlation coefficients are reported
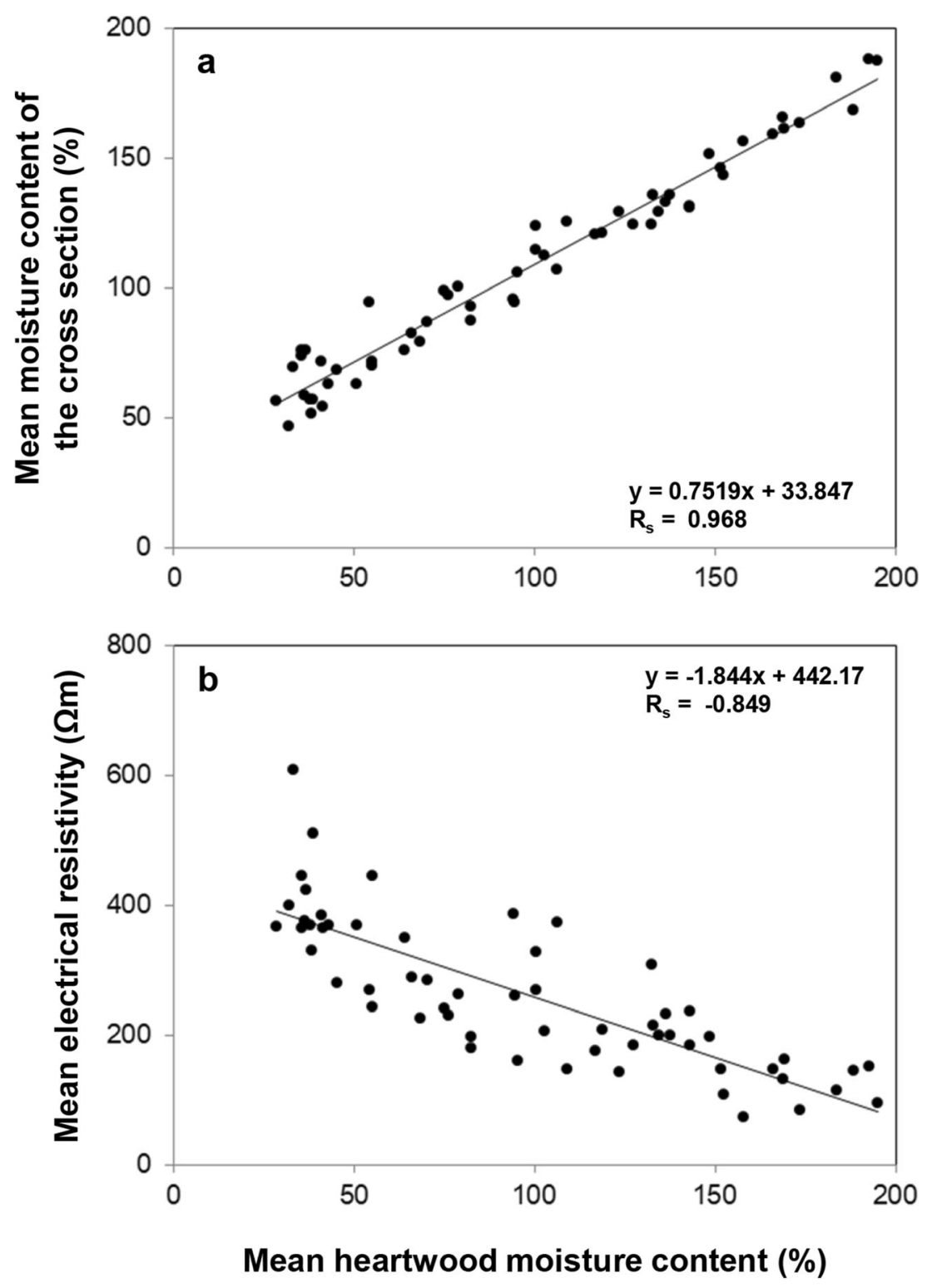

\subsection{ERT monitoring of moisture variations in standing trees}

\subsubsection{Seasonal fluctuations}

The ERT monitoring of trunks during more than 1 year showed that $\mathrm{ER}_{\text {mean }}$ varied significantly over the seasons, independently of the plot (Fig. 7). For the 44 trees studied, the highest ER values were measured during the winter months (November to March) and the lowest during the summer months (June to August). $\mathrm{ER}_{\text {mean }}$ gradually increased between September and December (+30\% compared to June for Guery 1 and Saint-Germain) and reached a peak in March at all sites. Then, $\mathrm{ER}_{\text {mean }}$ values decreased sharply to reach values up to $20 \%$ lower than those measured in May (Fig. 7). The results also showed that the profiles remained rather constant over the 16 months, for both dry and wet heartwood trees (data not shown).

\subsubsection{Girdling experiment}

Figure 8 shows the evolution in the water status of a tree, artificially caused by the girdling of sapwood, using MC measurements on cores and ERT. Based on MC measurements, the sapwood was completely dry 10 days after girdling. However, this decrease in MC could not be visualized by ERT at that time. This dry zone could finally be observed by ERT 90 days after girdling, in the form of a strong increase in ER measured on the outermost $4 \mathrm{~cm}$ of the trunk wood. 
Fig. $7 \mathrm{ER}_{\text {mean }}$ measured from May 2018 to August 2019 on 44 fir trees (15 in Guery 1, 20 in Guery 2, and 9 in Saint-Germain). Each point corresponds to the mean $( \pm \mathrm{SE})$ of the $\mathrm{ER}_{\text {mean }}$ as a percentage of the first measurement for each of the 3 study sites

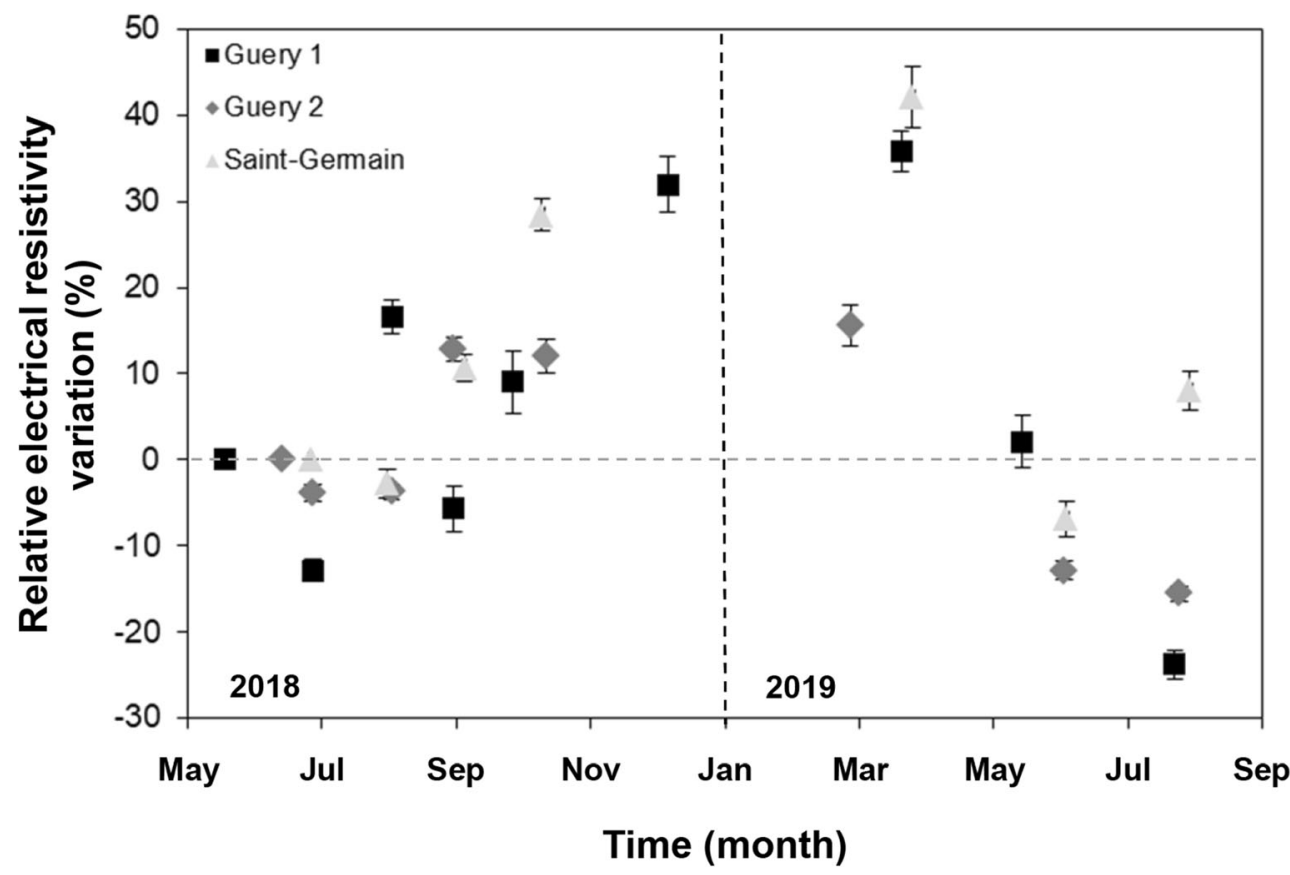

\section{Discussion}

This study revealed a high variability of ER profiles for the silver fir trees, which showed complex heterogeneous tomograms in almost half of the cases. Previous studies on conifers have shown very concentric ER profiles with a clear peripheral ring of low ER corresponding to the sapwood and a strong increase in ER towards the central zone corresponding to heartwood (Bär et al. 2019; Bieker and Rust 2010b; Ganthaler et al. 2019; Guyot et al. 2013). In our study, only $10 \%$ out of the 58 firs displayed this type of profile (type 1). Nevertheless, the mean $\mathrm{ER}_{\text {mean }}$ values of these 6 silver fir trees remained 2 to 3 times lower than the mean $\mathrm{ER}_{\text {mean }}$ values observed for spruce and Douglas fir from the same forests (Appendix Table 2). The other $90 \%$ of silver fir trees showed ER profiles with partially (type 2) or fully (type 3) lower resistivity values in the heartwood than in the sapwood, a pattern often described as typical for angiosperms (Bär et al. 2019; Bieker and Rust 2010a; Ganthaler et al. 2019) or spruces with decay (Humplik et al. 2016). The low $E_{\text {mean }}$ values of 311 and $166 \Omega \mathrm{m}$ obtained for typical ER profiles 2 and 3, respectively, were also comparable to those previously observed for birch $(\approx 250 \Omega \mathrm{m})$ and beech $(\approx 170 \Omega \mathrm{m})$ (Bär et al. 2019; Ganthaler et al. 2019).

Unlike other coniferous species in temperate forests, whose heartwood is generally homogeneously dry (Bär et al. 2019; Nakada 2006; Appendix Table 2), $83 \%$ of the 58 Abies alba trees studied showed a wetter heartwood with the heterogeneous spatial distribution of MC
(Fig. 2; Appendix Table 1). This high proportion of trees showing wetwood, coupled with high heterogeneity in terms of moisture level between individuals, has been observed by other authors for many fir species (Coutts and Rishbeth 1977; Jeremic et al. 2004; Lihra et al. 2000; Schneider and Zhou 1989; Worrall and Parmeter 1982). MC measurements also revealed a strong heterogeneity of the mean MC within the heartwood (from 28 to $192 \%$ ) compared to the homogeneity of the sapwood (mostly between 100 and 150\%). Indeed, the sapwood has always displayed identical patterns of mainly functional, water-filled tracheids in the earlywood and mostly or completely embolized tracheids in the latewood (Fig. $3 \mathrm{a})$. This type of regular pattern indicates that the silver fir trees studied had probably experienced in situ water stress (Dalla-Salda et al. 2014). This regularity was not found in the heartwood, which could display areas that were completely embolized, which considerably decreased the mean $\mathrm{MC}$, and large areas where all tracheids were filled with water, which, on the other hand, greatly increased the mean MC (Fig. 3).

Previous ERT studies on numerous coniferous species have shown a direct relationship between MC and ER along with radial profiles (Bär et al. 2019; Bieker and Rust 2010b; Guyot et al. 2013; Losso et al. 2020). In the case of silver fir, the comparison of radial MC profiles with the corresponding ER profiles (Fig. 2) highlighted that (i) for more than $80 \%$ of the wood samples, there was a pronounced negative relationship between the local MC of the wood and its resistivity, and (ii) for the other $20 \%$, ER tomography did not allow visualization and localization of the wetwood areas. 
Fig. 8 MC profiles of cores (blue) and corresponding radial ER profiles (red) of a girdling tree, the day of girdling (day 0 ), 10 and 90 days after girdling (day 10 and day 90). On each profile, the sapwood part is highlighted in gray. Each point of the MC profiles corresponds to a $1-\mathrm{cm}$ long core sample. ER values were extracted along with a 2 -cm width corresponding to the position of the core. MC values and the corresponding ER values are displayed according to their position $(0 \mathrm{~cm}$ corresponds to the trunk center)
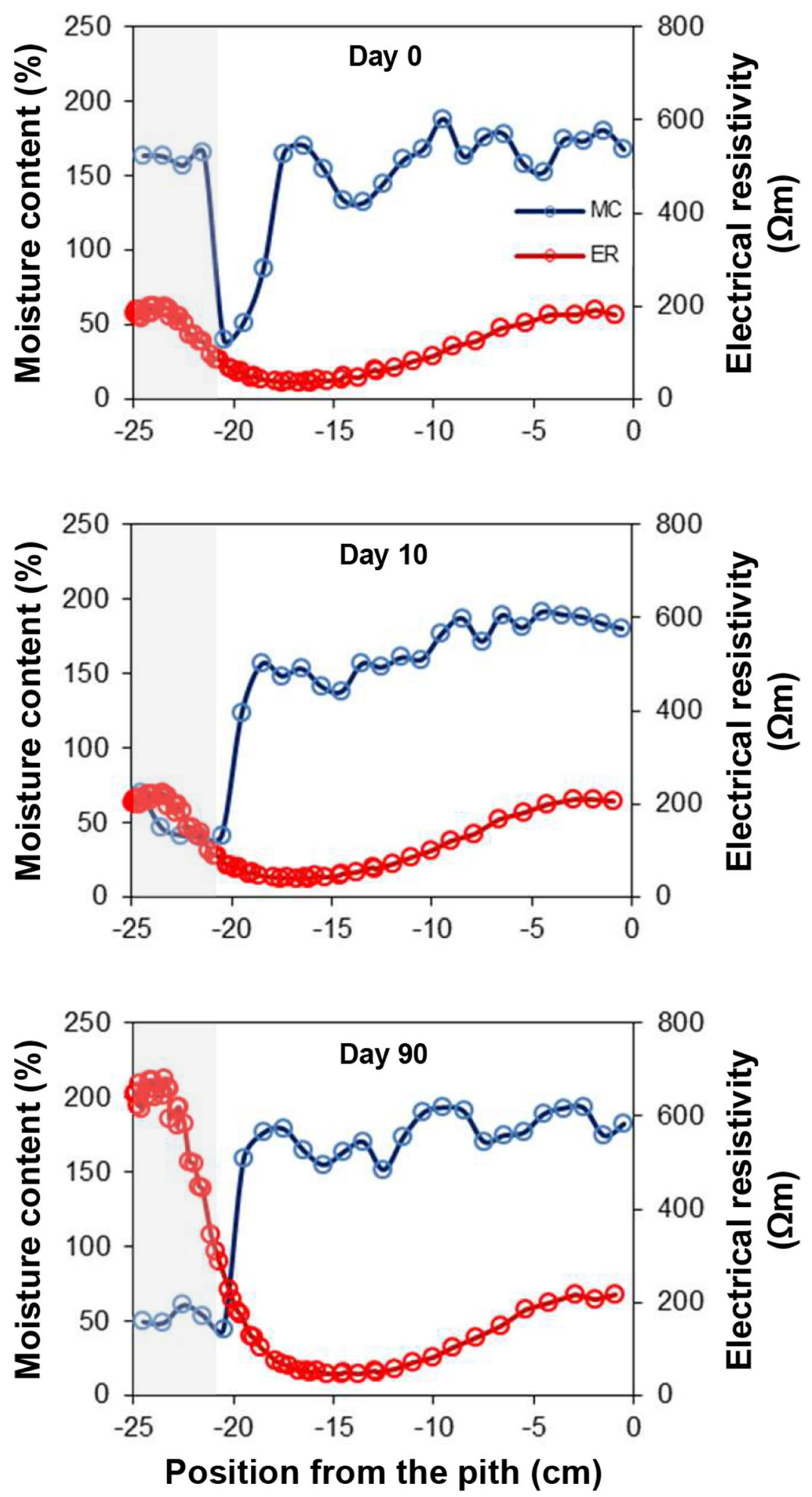

However, this global observation can be refined according to the type of ER profiles: The local ER-MC relationship was strong for $96 \%$ of the samples corresponding to type 1 and 3 ER profiles. This can be explained by the fact that these two types of ER profiles were characterized by two pronounced and homogeneous zones: The heartwood which was depicted by a high ER (red in tomograms, type 1) or low ER (blue, type 3) disk 
and the sapwood by low ER peripheral ring (Fig. 1). The corresponding MC profiles were also characterized by homogeneously dry heartwood for type 1 ER profile or wet heartwood for type 3 (data not shown). The high ER values observed in the center of each "type 1 profile" tomogram were due to the presence of homogeneously dry heartwood, as observed in previous studies (Bär et al. 2019; Bieker and Rust 2010b; Guyot et al. 2013; Losso et al. 2020). On the contrary, the low ER values observed on the tomograms of the trees corresponding to type 3 were always due to the presence of large areas of wetwood.

For the trees displaying a type 2 profile, ER tomograms analysis was more difficult with a poor correlation with MC observed for $32 \%$ of the samples. Heterogeneous ER profiles, varying from one tree to another and showing complex heterogeneous patterns, associated with a high variability of MC profiles between cores made on the same tree probably explain such low local correlations. In addition, the comparison of ER tomograms with real radial cuts and 3D X-ray CT scanning images made it clear that ERT was able to highlight dry or wet homogenous heartwood, but failed to map heterogenous wetwood zones (Fig. 4). This type of conclusion has also been observed in the case of decay detection in Norway spruce (Humplik et al. 2016). Although ERT measurements do not accurately map the MC of the tree at a fine spatial scale, the stable hydric status of the sapwood allowed to conclude on the overall hydric status of the trunk and thus of the heartwood (Figs. 5 and 6).

In the case of single-tree monitoring, ERT has proven its efficiency for the nondestructive evaluation of tree water loss (Fig. 8). In the case of the girdling tree, the decrease in MC observed only on the $5 \mathrm{~cm}$ of sapwood was visible on ER profiles by a clear increase in ER a few weeks after treatment. The absence of variation in ER profiles despite a large decrease in MC 10 days after girdling could be due to the presence of some local electrical connections at 10 days that would have completely disappeared after 90 days. This could be used to evaluate drought mortality, especially during severe drought.

Our ER raw values seemed to show an impact of the season during which the measurements were performed and the variability due to the location of the forests (Fig. 7, Appendix Table 1). A significant increase in ER values was observed between November and March, a period during which average temperatures remained below $5^{\circ} \mathrm{C}$ for the 3 study sites. Effects of the winter season and lower temperatures on the overall increase in ER values have already been highlighted in previous studies (Ganthaler et al. 2019; Larsson et al. 2004; Luo et al. 2019). Using the temperature correction model of Luo et al. (2019), we observed that the ER of the trunks remained very stable whatever the season (Fig. 9). The variation in ER values we measured could be due to a change in viscosity and thus in the mobility of the ions with temperature (Tattar and Blanchard 1976). Differences in mean ER values between the 3 sites could be related to physical properties of the wood, such as density, which could be influenced by local growing conditions (trees of Guery 2 that grew on a steep slope probably formed more reaction wood than trees growing on the other plots) or the electrolyte content of the soil (Bär et al. 2019; Bieker and Rust 2010a; Guyot et al. 2013). Regarding these results about the sources of variability, we suggest taking care of the season during which ER measurements are performed and being cautious in case of comparison between forest plots.

\section{Conclusion}

The present study confirms the complexity of using ERT in the study of wetwood by displaying several drawbacks: (i) It does not provide an accurate and precise information on the exact location of wetwood, especially when its spatial distribution is heterogeneous; (ii) in many typical cases, it clearly indicates the water status of the heartwood and sapwood, and thus the possible presence of large homogeneous wetwood areas; and (iii) the sources of variability are numerous (season, forest plot position, etc.), and many precautions need to be taken in case of forest plot comparison. However, taking all these aspects into account, our results indicate that the ERT method can be used to estimate the overall moisture content of silver fir trunks in a nondestructive way directly in the forest. This technique could be used to select the trees that should be harvested first in forest management or to monitor silvicultural experiments to reduce the size or occurrence of water pockets. Moreover, the good repeatability of the measurements allows the monitoring of single trees in order to follow the relative variations of ERT. It could be a relevant, fast, and nondestructive technique to evaluate the hydric status of standing trees, especially during water stress events which are increasingly frequent in the current climate change context. ERT could be used as a complementary tool to water potential and allow nondestructive quantification of the water status of trees during droughts and thus help better understand their response. Thus, ERT displays the great potential to study the proportion of silver fir trees with wetwood and represents an attractive tool for scientists and forest managers. 


\section{Appendix}

Table 1 Main characteristics of the 58 silver fir trees. Tree age (number of annual rings at $125-\mathrm{cm}$ height), trunk diameter at $130-\mathrm{cm}$ height, number of inserted electrodes, moisture content $(\mathrm{MC}$; mean $\pm \mathrm{SE}$ when
2 to 3 cores were collected), and electrical resistivity (ER; mean $\pm \mathrm{SE}$ ) parameters. Mean data of each forest are given with the SD

\begin{tabular}{|c|c|c|c|c|c|c|c|c|}
\hline Forest & Tree & $\begin{array}{l}\text { Age } \\
\text { (years) }\end{array}$ & $\begin{array}{l}\text { Diameter } \\
(\mathrm{cm})\end{array}$ & $\begin{array}{l}\text { Number of } \\
\text { electrodes }\end{array}$ & $\begin{array}{l}\text { ERmean 31/07-02/08/ } \\
2018(\Omega \mathrm{m})\end{array}$ & $\begin{array}{l}\text { Mean sapwood } \\
\text { MC (\%) }\end{array}$ & $\begin{array}{l}\text { Mean heartwood } \\
\text { MC (\%) }\end{array}$ & $\begin{array}{l}\text { Mean total } \\
\text { MC }(\%)\end{array}$ \\
\hline \multirow[t]{24}{*}{ Guery 1} & 1 & 63 & 50.9 & 24 & $175.4 \pm 1.5$ & $123.3 \pm 17.3$ & $116.7 \pm 3.0$ & $120.7 \pm 1.0$ \\
\hline & 2 & 61 & 47.1 & 24 & $239.9 \pm 1.4$ & $154.0 \pm 8.9$ & $75.1 \pm 28.9$ & $98.6 \pm 19.1$ \\
\hline & 3 & 69 & 42.0 & 24 & $376.0 \pm 2.8$ & 120.9 & 36.2 & 58.3 \\
\hline & 4 & 69 & 47.7 & 24 & $159.1 \pm 1.2$ & $140.4 \pm 4.9$ & $95.5 \pm 4.1$ & $105.7 \pm 0.7$ \\
\hline & 5 & 69 & 45.2 & 24 & $609.3 \pm 5.4$ & $162.4 \pm 1.4$ & $33.2 \pm 0.6$ & $69.6 \pm 3.3$ \\
\hline & 6 & 76 & 58.9 & 24 & $146.1 \pm 1.1$ & $148.8 \pm 4.2$ & $109.1 \pm 17.6$ & $125.2 \pm 7.1$ \\
\hline & 7 & 70 & 61.1 & 24 & $147.9 \pm 0.9$ & 144.0 & 166.1 & 159.0 \\
\hline & 8 & 69 & 49.3 & 24 & $147.1 \pm 1.5$ & $123.0 \pm 3.9$ & $151.6 \pm 2.4$ & $146.3 \pm 2.4$ \\
\hline & 9 & 76 & 50.0 & 24 & $163.0 \pm 1.7$ & $135.9 \pm 28.2$ & $169.0 \pm 8.1$ & $161.2 \pm 0.4$ \\
\hline & 10 & 64 & 61.1 & 24 & $84.5 \pm 0.8$ & 139.6 & 173.5 & 163.7 \\
\hline & 11 & 65 & 63.0 & 24 & $106.8 \pm 1.2$ & 112.8 & 152.2 & 143.6 \\
\hline & 12 & 61 & 58.6 & 24 & $150.3 \pm 2.8$ & 174.2 & 192.7 & 188.0 \\
\hline & 13 & 64 & 36.6 & 18 & $225.4 \pm 3.3$ & 103.6 & 68.3 & 79.3 \\
\hline & 14 & 64 & 57.6 & 24 & $94.5 \pm 1.2$ & 159.8 & 195.0 & 187.3 \\
\hline & 15 & 63 & 58.3 & 24 & $114.3 \pm 1.4$ & 170.4 & 183.6 & 180.7 \\
\hline & 16 & 68 & 67.8 & 24 & $145.5 \pm 1.8$ & 113.7 & 188.2 & 168.5 \\
\hline & 17 & 66 & 66.2 & 24 & $205.5 \pm 1.1$ & 139.7 & 102.7 & 112.5 \\
\hline & 18 & 60 & 38.2 & 20 & $369.7 \pm 2.7$ & $112.1 \pm 7.3$ & $43.1 \pm 4.0$ & $62.9 \pm 7.9$ \\
\hline & 19 & 56 & 42.7 & 22 & $198.2 \pm 1.6$ & 118.2 & 134.5 & 129.4 \\
\hline & 20 & 59 & 33.7 & 18 & $259.3 \pm 4.2$ & $94.0 \pm 1.9$ & $94.7 \pm 27.7$ & $94.5 \pm 20.2$ \\
\hline & 21 & 60 & 39.5 & 20 & $510.1 \pm 4.5$ & 97.2 & 38.6 & 56.9 \\
\hline & 22 & 62 & 35.0 & 18 & $180.2 \pm 2.1$ & $115.0 \pm 1.9$ & $82.5 \pm 9.8$ & $93.0 \pm 6.8$ \\
\hline & 23 & 61 & 46.8 & 24 & $72.1 \pm 1.1$ & $148.3 \pm 13.9$ & $158.0 \pm 8.0$ & $156.7 \pm 5.3$ \\
\hline & Mean & $\begin{array}{c}65.0 \pm \\
5.1\end{array}$ & $\begin{array}{r}50.3 \pm \\
10.3\end{array}$ & $22.8 \pm 2.2$ & $212.2 \pm 134.9$ & $133.7 \pm 23.0$ & $120.0 \pm 54.6$ & $124.4 \pm 42.6$ \\
\hline \multirow[t]{16}{*}{ Guery 2} & 1 & 67 & 39.5 & 20 & $289.0 \pm 2.0$ & 103.3 & 65.9 & 82.4 \\
\hline & 2 & 64 & 36.9 & 20 & $424.1 \pm 2.9$ & 123.2 & 36.6 & 76.0 \\
\hline & 3 & 59 & 34.4 & 18 & $365.1 \pm 4.9$ & 130.8 & 35.5 & 75.9 \\
\hline & 4 & 63 & 56.0 & 24 & $200.2 \pm 1.4$ & 131.9 & 137.6 & 136.0 \\
\hline & 5 & 60 & 41.7 & 20 & $369.6 \pm 2.8$ & 118.6 & 50.7 & 62.7 \\
\hline & 6 & 58 & 42.0 & 20 & $383.2 \pm 2.6$ & $107.4 \pm 12.7$ & $40.9 \pm 2.5$ & $71.8 \pm 7.4$ \\
\hline & 7 & 57 & 39.5 & 20 & $232.7 \pm 2.3$ & $129.5 \pm 7.5$ & $136.5 \pm 12.7$ & $133.2 \pm 10.3$ \\
\hline & 8 & 66 & 38.2 & 20 & $214.8 \pm 2.3$ & $140.7 \pm 13.4$ & $132.8 \pm 0.5$ & $136.0 \pm 5.6$ \\
\hline & 9 & 73 & 65.6 & 24 & $196.5 \pm 2.0$ & $158.0 \pm 3.4$ & $148.4 \pm 1.8$ & $151.7 \pm 0.6$ \\
\hline & 10 & 58 & 50.6 & 24 & $269.7 \pm 1.6$ & $151.4 \pm 0.6$ & $54.3 \pm 1.3$ & $94.5 \pm 1.4$ \\
\hline & 11 & 71 & 52.8 & 24 & $233.9 \pm 0.9$ & $141.3 \pm 9.3$ & $76.3 \pm 5.7$ & $97.0 \pm 1.9$ \\
\hline & 12 & 63 & 34.4 & 18 & $279.4 \pm 2.7$ & $104.7 \pm 3.2$ & $45.4 \pm 4.2$ & $68.5 \pm 4.6$ \\
\hline & 13 & 61 & 45.2 & 22 & $284.2 \pm 3.5$ & $129.6 \pm 0.2$ & $70.2 \pm 0.7$ & $86.7 \pm 2.9$ \\
\hline & 14 & 60 & 46.2 & 24 & $207.3 \pm 2.0$ & $128.1 \pm 4.2$ & $118.6 \pm 0.6$ & $121.0 \pm 0.6$ \\
\hline & 15 & 59 & 37.6 & 20 & $262.1 \pm 2.4$ & $126.5 \pm 2.5$ & $78.8 \pm 8.1$ & $100.2 \pm 5.4$ \\
\hline & 16 & 57 & 33.1 & 18 & $444.7 \pm 3.6$ & $117.4 \pm 4.6$ & $35.4 \pm 3.0$ & $73.7 \pm 3.4$ \\
\hline
\end{tabular}


Table 1 (continued)

\begin{tabular}{|c|c|c|c|c|c|c|c|c|}
\hline Forest & Tree & $\begin{array}{l}\text { Age } \\
\text { (years) }\end{array}$ & $\begin{array}{l}\text { Diameter } \\
(\mathrm{cm})\end{array}$ & $\begin{array}{l}\text { Number of } \\
\text { electrodes }\end{array}$ & $\begin{array}{l}\text { ERmean 31/07-02/08/ } \\
2018(\Omega \mathrm{m})\end{array}$ & $\begin{array}{l}\text { Mean sapwood } \\
\text { MC }(\%)\end{array}$ & $\begin{array}{l}\text { Mean heartwood } \\
\text { MC (\%) }\end{array}$ & $\begin{array}{l}\text { Mean total } \\
\text { MC }(\%)\end{array}$ \\
\hline & 17 & 60 & 39.2 & 20 & $268.5 \pm 2.9$ & $132.4 \pm 1.6$ & $100.3 \pm 21.2$ & $114.6 \pm 12.7$ \\
\hline & 18 & 67 & 53.2 & 24 & $242.2 \pm 1.6$ & $102.6 \pm 2.7$ & $55.2 \pm 10.8$ & $70.2 \pm 6.9$ \\
\hline & 19 & 59 & 28.0 & 16 & $369.9 \pm 3.0$ & 80.7 & 37.8 & 56.9 \\
\hline & 20 & 62 & 46.8 & 24 & $328.6 \pm 1.7$ & $159.3 \pm 12.1$ & $100.3 \pm 25.6$ & $124.0 \pm 17.7$ \\
\hline & Mean & $\begin{array}{c}62.2 \pm \\
4.6\end{array}$ & $43.0 \pm 9.1$ & $21.0 \pm 2.5$ & $293.1 \pm 76.3$ & $125.9 \pm 19.7$ & $77.9 \pm 39.1$ & $96.7 \pm 28.7$ \\
\hline \multirow[t]{17}{*}{ Saint-Germain } & 1 & 111 & 64.6 & 24 & $183.9 \pm 2.0$ & 119.5 & 142.9 & 131.5 \\
\hline & 2 & 136 & 51.2 & 24 & $365.7 \pm 2.5$ & 93.5 & 41.3 & 54.4 \\
\hline & 3 & 151 & 85.9 & 24 & $142.3 \pm 1.8$ & 136.3 & 123.4 & 129.3 \\
\hline & 4 & 115 & 56.7 & 24 & $386.1 \pm 4.8$ & $121.9 \pm 25.9$ & $94.1 \pm 9.3$ & $95.8 \pm 7.6$ \\
\hline & 5 & 108 & 49.3 & 24 & $236.0 \pm 2.6$ & 97.3 & 143.0 & 130.9 \\
\hline & 6 & 118 & 50.3 & 24 & $348.9 \pm 2.1$ & $107.1 \pm 25.5$ & $64.0 \pm 10.2$ & $76.1 \pm 15.8$ \\
\hline & 7 & 128 & 57.9 & 24 & $196.2 \pm 1.9$ & $103.6 \pm 6.8$ & $82.3 \pm 7.3$ & $87.2 \pm 7.5$ \\
\hline & 8 & 149 & 71.6 & 24 & $330.0 \pm 1.9$ & $100.4 \pm 11.2$ & $38.1 \pm 4.2$ & $51.2 \pm 5.6$ \\
\hline & 9 & 127 & 35.3 & 16 & $445.8 \pm 5.1$ & $119.2 \pm 0.0$ & $55.0 \pm 6.4$ & $71.6 \pm 7.9$ \\
\hline & 10 & 129 & 48.4 & 24 & $399.9 \pm 3.1$ & 111.3 & 31.8 & 46.3 \\
\hline & 11 & 114 & 60.5 & 24 & $367.2 \pm 2.4$ & 120.2 & 28.4 & 56.3 \\
\hline & 12 & 142 & 70.7 & 24 & $184.3 \pm 1.8$ & 114.5 & 127.2 & 124.1 \\
\hline & 13 & 105 & 51.6 & 24 & $374.2 \pm 3.5$ & $108.9 \pm 5.4$ & $106.3 \pm 6.5$ & $106.7 \pm 2.8$ \\
\hline & 14 & 107 & 51.9 & 24 & $307.4 \pm 2.1$ & $102.9 \pm 9.5$ & $132.6 \pm 6.8$ & $124.6 \pm 3.0$ \\
\hline & 15 & 122 & 64.0 & 24 & $131.3 \pm 1.8$ & 158.0 & 168.8 & 165.9 \\
\hline & Mean & $\begin{array}{c}124.1 \pm \\
15.0\end{array}$ & $\begin{array}{r}58.0 \pm \\
12.2\end{array}$ & $23.5 \pm 2.1$ & $293.28 \pm 103.77$ & $114.3 \pm 16.5$ & $91.9 \pm 46.7$ & $96.8 \pm 36.9$ \\
\hline & $\begin{array}{l}\text { Mean } \\
\text { overall }\end{array}$ & $\begin{array}{r}79.3 \pm \\
28.1\end{array}$ & $\begin{array}{r}49.8 \pm \\
11.8\end{array}$ & $22.3 \pm 2.5$ & $261.1 \pm 114.9$ & $125.6 \pm 21.3$ & $98.2 \pm 50.4$ & $107.7 \pm 38.7$ \\
\hline
\end{tabular}

Table 2 Main characteristics of the 7 spruce and 5 Douglas fir trees. Tree age (number of annual rings at $125-\mathrm{cm}$ height), trunk diameter at $130-\mathrm{cm}$ height, number of inserted electrodes, moisture content (MC),

\begin{tabular}{|c|c|c|c|c|c|c|c|c|}
\hline Forest & Tree & $\begin{array}{l}\text { Age } \\
\text { (years) }\end{array}$ & $\begin{array}{l}\text { Diameter } \\
(\mathrm{cm})\end{array}$ & $\begin{array}{l}\text { Number of } \\
\text { electrodes }\end{array}$ & $\begin{array}{l}\text { ERmean 31/07-02/08/ } \\
2018(\Omega \mathrm{m})\end{array}$ & $\begin{array}{l}\text { Mean sapwood } \\
\text { MC }(\%)\end{array}$ & $\begin{array}{l}\text { Mean heartwood } \\
\text { MC }(\%)\end{array}$ & $\begin{array}{l}\text { Mean total } \\
\text { MC }(\%)\end{array}$ \\
\hline & Spruce 1 & 51 & 41.4 & 20 & $1196.2 \pm 17.5$ & 111.3 & 35.7 & 58.0 \\
\hline & Spruce 2 & 54 & 57.3 & 24 & $723.7 \pm 4.6$ & 117.4 & 31.8 & 46.5 \\
\hline & Spruce 3 & 49 & 44.2 & 20 & $779.0 \pm 4.0$ & 102.5 & 31.1 & 43.7 \\
\hline & Spruce 4 & 51 & 53.5 & 24 & $670.0 \pm 2.5$ & 112.9 & 34.8 & 53.8 \\
\hline & Spruce 5 & 66 & 64.9 & 24 & $939.1 \pm 10.4$ & 131.5 & 33.4 & 59.4 \\
\hline & Spruce 6 & 60 & 62.4 & 24 & $1149.9 \pm 12.7$ & 107.9 & 29.0 & 40.6 \\
\hline \multirow[t]{2}{*}{ Saint-Germain } & Spruce 7 & 84 & 47.1 & 24 & $890.2 \pm 7.0$ & 98.7 & 28.2 & 47.4 \\
\hline & Mean & $\begin{array}{r}59.3 \pm \\
12.4\end{array}$ & $53.0 \pm 9.1$ & $22.9 \pm 2.0$ & $906.9 \pm 204.2$ & $111.7 \pm 10.8$ & $32.0 \pm 2.8$ & $49.9 \pm 7.2$ \\
\hline \multirow[t]{4}{*}{ Saint-Germain } & $\begin{array}{c}\text { Douglas } \\
1\end{array}$ & 88 & 65.9 & 24 & $1379.6 \pm 8.7$ & 124.2 & 31.3 & 49.9 \\
\hline & $\begin{array}{c}\text { Douglas } \\
2\end{array}$ & 89 & 66.8 & 24 & $1525.9 \pm 11.8$ & 96.1 & 32.2 & 43.8 \\
\hline & $\begin{array}{c}\text { Douglas } \\
3\end{array}$ & 89 & 73.2 & 24 & $1183.4 \pm 8.1$ & 111.3 & 33.4 & 60.2 \\
\hline & & 88 & 65 & 324 & $1262.1 \pm 3.8$ & 87.3 & 29.3 & 40.2 \\
\hline
\end{tabular}

and electrical resistivity (ER; mean $\pm \mathrm{SE}$ ) parameters. Mean data of each species are given with the SD 
Table 2 (continued)

\begin{tabular}{|c|c|c|c|c|c|c|c|c|}
\hline Forest & Tree & $\begin{array}{l}\text { Age } \\
\text { (years) }\end{array}$ & $\begin{array}{l}\text { Diameter } \\
(\mathrm{cm})\end{array}$ & $\begin{array}{l}\text { Number of } \\
\text { electrodes }\end{array}$ & $\begin{array}{l}\text { ERmean 31/07-02/08/ } \\
2018(\Omega \mathrm{m})\end{array}$ & $\begin{array}{l}\text { Mean sapwood } \\
\text { MC }(\%)\end{array}$ & $\begin{array}{l}\text { Mean heartwood } \\
\text { MC }(\%)\end{array}$ & $\begin{array}{l}\text { Mean total } \\
\text { MC }(\%)\end{array}$ \\
\hline & \multicolumn{8}{|l|}{$\begin{array}{c}\text { Douglas } \\
4\end{array}$} \\
\hline & $\begin{array}{c}\text { Douglas } \\
5\end{array}$ & 87 & 60.5 & 24 & $1387.7 \pm 11.6$ & 115.2 & 30.7 & 46.0 \\
\hline & Mean & $\begin{array}{c}88.2 \pm \\
0.8\end{array}$ & $66.3 \pm 4.6$ & $24.0 \pm 0.0$ & $1347.8 \pm 131.0$ & $106.8 \pm 14.9$ & $31.4 \pm 1.5$ & $48.0 \pm 7.6$ \\
\hline
\end{tabular}

Fig. 9 Electrical resistivities (ER) measured from May 2018 to August 2019 on 44 fir trees (15 at Guery 1, 20 at Guery 2, and 9 at Saint-Germain). Each close point corresponds to the mean of the raw measured ERs for each of the 3 study sites (to facilitate visualization, $\mathrm{SE}$ has been removed). Open points correspond to the simulation of ER values computed according to the Lou et al. (2019) model in case of the electric properties of the trunk keep stable, and only the temperature (here the monthly mean) changes. The good similarities between the raw and simulated curves show that the variations of measured $E R$ values over the seasons are clearly due to the temperature effect

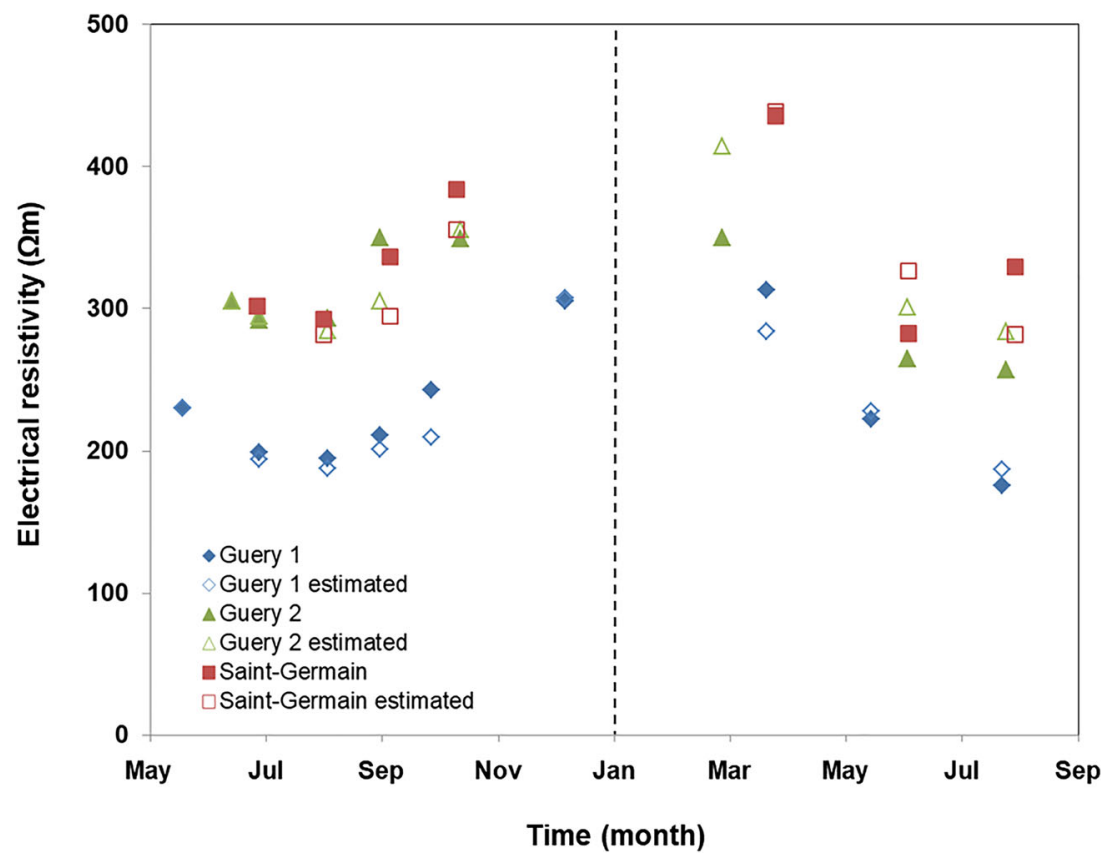

Acknowledgements The authors would like to thank the SILVATECH platform (INRAE-Nancy, https://www6.nancy.inrae.fr/silva/Plateformes/ SilvaTech) for the X-ray CT scanning of the logs and Julien Cartailler and Pierre Conchon for their help with forest measurements and X-ray microtomography, respectively.

Author contribution Experimental design: Ludovic Martin, Hervé Cochard, and Eric Badel

Data analysis: Ludovic Martin

First draft: Ludovic Martin

Final writing: Ludovic Martin, Hervé Cochard, Stefan Mayr, and Eric Badel

Funding acquisition: Hervé Cochard

Funding This study was part of the Sap-In project AV0014860 funded by the European Regional Development Fund (ERDF) within the framework of the ERDF/ESF Auvergne operational program for the 2014-2020 programming period. This work was also supported by the Austrian Science Fund FWF, grant no. P32203.

Availability of data and materials The datasets generated and/or analyzed during the current study are available in the Data INRAE repository, https://doi.org/10.15454/VT1CSA.

\section{Declarations}

Consent for publication All authors gave their informed consent to this publication and its content.

Conflict of interest The authors declare no competing interests. 


\section{References}

Al Hagrey SA (2006) Electrical resistivity imaging of tree trunks. Near Surf Geophys 4:179-187

Al Hagrey SA (2007) Geophysical imaging of root-zone, trunk, and moisture heterogeneity. J Exp Bot 58:839-854. https://doi.org/10. 1093/jxb/erl237

Alkan S, Zhang YL, Lam F (2007) Moisture distribution changes and wetwood behavior in subalpine fir wood during drying using high X-ray energy industrial CT scanner. Dry Technol 25:483-488. https://doi.org/10.1080/07373930601184023

Badel E, Martin L, Cochard H, Mayr S (2021) Monitoring of electric resistivity of trees in Auvergne (France), [dataset], Data INRAE repository, V1. 10.15454/VT1CSA

Baettig R, Cornejo J, Guajardo J (2017) Detection and delimitation of false heartwood in Populus using an electrical impedance method. Eur J Wood Prod 75:1003-1008. https://doi.org/10.1007/s00107$017-1176-9$

Bär A, Hamacher M, Ganthaler A, Losso A, Mayr S (2019) Electrical resistivity tomography: patterns in Betula pendula, Fagus sylvatica, Picea abies and Pinus sylvestris. Tree Physiol 39:1262-1271. https://doi.org/10.1093/treephys/tpz052

Bieker D, Rust S (2010a) Electric resistivity tomography shows radial variation of electrolytes in Quercus robur. Can J For Res 40:1189 1193. https://doi.org/10.1139/x10-076

Bieker D, Rust S (2010b) Non-destructive estimation of sapwood and heartwood width in Scots pine (Pinus sylvestris L.). Silva Fennica 44:267-273. https://doi.org/10.14214/sf.153

Bieker D, Kehr R, Weber G, Rust S (2010) Non-destructive monitoring of early stages of white rot by Trametes versicolor in Fraxinus excelsior. Ann For Sci 67. https://doi.org/10.1051/forest/2009103

Bonsen JM, Walter M (1993) Wetwood and its implications. Arboric J $17: 61-67$

Chafe SC (1996) Drying in thin sections of wetwood-infected hoop pine. Holzforschung 50:55-61. https://doi.org/10.1515/hfsg.1996.50.1. 55

Cochard H, Delzon S, Badel E (2015) X-ray microtomography (micro$\mathrm{CT})$ : a reference technology for high-resolution quantification of xylem embolism in trees. Plant Cell Environ 38:201-206. https:// doi.org/10.1111/pce.12391

Coutts MP, Rishbeth J (1977) Formation of wetwood in grand fir. Eur J Forest Pathol 7:13-22

Dalla-Salda G, Fernández ME, Sergent A-S, Rozenberg P, Badel E, Martinez-Meier A (2014) Dynamics of cavitation in a Douglas-fir tree-ring: transition-wood, the lord of the ring? J Plant Hydraul 1:e005. https://doi.org/10.20870/jph.2014.e005

Etheridge DE, Morin LA (1962) Wetwood formation in Balsam fir. Can J Bot 40:1335-1345. https://doi.org/10.1139/b62-127

Ganthaler A, Sailer J, Bär A, Losso A, Mayr S (2019) Noninvasive analysis of tree stems by electrical resistivity tomography: unraveling the effects of temperature, water status, and electrode installation. Front Plant Sci 10. https://doi.org/10.3389/fpls.2019. 01455

Goncz B, Divos F, Bejo L (2018) Detecting the presence of red heart in beech (Fagus sylvatica) using electrical voltage and resistance measurements. Eur J Wood Wood Prod 76:679-686. https://doi.org/10. 1007/s00107-017-1225-4

Gunther T, Rucker C, Spitzer K (2006) Three-dimensional modelling and inversion of DC resistivity data incorporating topography - II. Inversion. Geophys J Int 166:506-517. https://doi.org/10.1111/j. 1365-246X.2006.03011.x

Guyot A, Ostergaard KT, Lenkopane M, Fan JL, Lockington DA (2013) Using electrical resistivity tomography to differentiate sapwood from heartwood: application to conifers. Tree Physiol 33:187-194. https://doi.org/10.1093/treephys/tps128
Humplik P, Cermak P, Zid T (2016) Electrical impedance tomography for decay diagnostics of Norway spruce (Picea abies): possibilities and opportunities. Silva Fennica 50:1341

Jeremic D, Cooper P, Srinivasan U (2004) Comparative analysis of balsam fir wetwood, heartwood, and sapwood properties. Can J For Res 34:1241-1250. https://doi.org/10.1139/x03-287

Just A, Jacobs F (1998) Elektrische Widerstandstomographie zur Untersuchung des Gesundheitszustandes von Baumen. In Proceedings: Tagungsband des VII. Arbeitsseminars, "hochauflosende Geoelektrik". Institut für Geophysik und Geologie der Universität Leipzig, Germany

Kozlik CJ, Ward JC (1981) Properties and kiln-drying characteristics of young-growth western hemlock dimension lumber. For Prod J 31: $45-53$

Krause C, Gagnon R (2005) Wet heartwood distribution in the stem, stump, and root wood of black spruce in the Quebec boreal forest, Canada. North J Appl For 22:12-18. https://doi.org/10.1093/njaf/ 22.1.12

Krause C, Gagnon R (2006) The relationship between site and tree characteristics and the presence of wet heartwood in black spruce in the boreal forest of Quebec, Canada. Can J For Res 36:1519-1526. https://doi.org/10.1139/x06-026

Larsson B, Bengtsson B, Gustafsson M (2004) Nondestructive detection of decay in living trees. Tree Physiol 24:853-858. https://doi.org/10. 1093/treephys/24.7.853

Lihra T, Cloutier A, Zhang SY (2000) Longitudinal and transverse permeability of balsam fir wetwood and normal heartwood. Wood Fiber Sci 32:164-178

Losso A, Sailer J, Baer A, Ganthaler A, Mayr S (2020) Insights into trunks of Pinus cembra L.: analyses of hydraulics via electrical resistivity tomography. Trees-Structure and Function 34:999-1008. https://doi.org/10.1007/s00468-020-01976-x

Luo ZD, Guan HD, Zhang XP (2019) The temperature effect and correction models for using electrical resistivity to estimate wood moisture variations. Journal of Hydrology 578:124022. https://doi.org/10. 1016/j.jhydrol.2019.124022

Martin T, Gunther T (2013) Complex resistivity tomography (CRT) for fungus detection on standing oak trees. Eur J For Res 132:765-776. https://doi.org/10.1007/s10342-013-0711-4

Nakada R (2006) Within-stem water distribution in living trees of some conifers. IAWA J 27:313-327

Nakada R, Okada N, Nakai T, Kuroda K, Nagai S (2019) Water potential gradient between sapwood and heartwood as a driving force in water accumulation in wetwood in conifers. Wood Sci Technol 53:407424. https://doi.org/10.1007/s00226-019-01081-4

Revil A, Karaoulis M, Johnson T, Kemna A (2012) Review: some lowfrequency electrical methods for subsurface characterization and monitoring in hydrogeology. Hydrogeol J 20:617-658. https://doi. org/10.1007/s10040-011-0819-x

Schink B, Ward JC (1984) Microaerobic and anaerobic bacterial activities involved in formation of wetwood and discoloured wood. IAWA J 5:105-109. https://doi.org/10.1163/22941932-90000872

Schneider MH, Zhou L (1989) Characterization of wetwood from 4 balsam fir trees. Wood Fiber Sci 21:1-16

Shaw DC, Edmonds RL, Littke WR, Browning JE, Russel KW (1995) Incidence of wetwood and decay in precommercially thinned western hemlock stands. Can J For Res 25:1269-1277. https://doi.org/ $10.1139 / \mathrm{x} 95-140$

Skaar C (1988) Wood-water relations. Springer- Verlag, Heidelberg

Suuronen JP, Peura M, Fagerstedt K, Serimaa R (2013) Visualizing water-filled versus embolized status of xylem conduits by desktop X-ray microtomography. Plant Methods 9:11. https://doi.org/10. 1186/1746-4811-9-11

Tattar TA, Blanchard RO (1976) Electrophysiological research in plant pathology. Annu Rev Phytopathol 14:309-325. https://doi.org/10. 1146/annurev.py.14.090176.001521 
Ward JC, Pong WY (1980) Wetwood in trees: a timber resource problem. USDA Forest Service General Technical Report PNW 112, USDA Forest Service Pacific Northwest Forest and Range Experimental Station

Watanabe K, Mansfield SD, Avramidis S (2012) Wet-pocket classification in Abies lasiocarpa using spectroscopy in the visible and near infrared range. Eur J Wood Wood Prod 70:61-67. https://doi.org/10. 1007/s00107-010-0490-2
Worrall JJ, Parmeter JR (1982) Formation and properties of wetwood in white fir. Phytopathology 72:1209-1212. https://doi.org/10.1094/ Phyto-77-1209

Publisher's note Springer Nature remains neutral with regard to jurisdictional claims in published maps and institutional affiliations. 